\title{
II - Contribuição para o Estudo Biológico e Ecológico das Podostemonaceae do Salto de Piracicaba
}

\section{Walter Radamés Accorsi}

Prof. de Botánica Geral e Descritiva da E. S. A. "Luiz de Queiroz"

INDICE

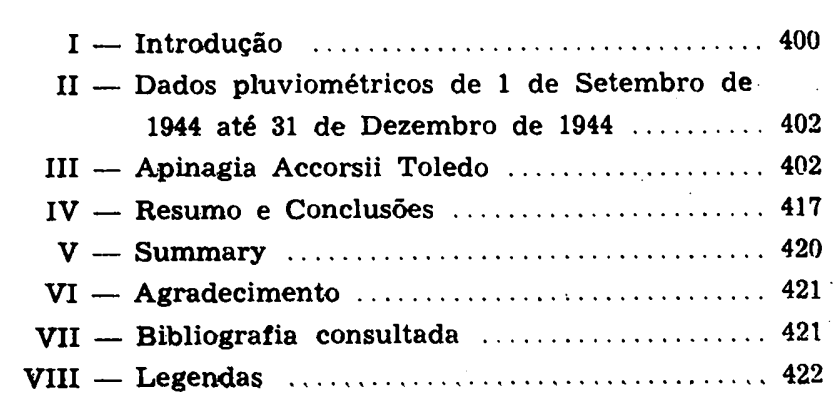




\section{INTRODUÇAO}

Na minha primeira contribuição sôbre as Podostemonaceae, que vivem no Salto de Piracicaba (ACCORSI 1944), ressaltei o comportamento biológico e ecológico das espécies Apinagia Accorsii Toledo e Mniopsis Glazioviana Warmg., num periodo de pouco mais de um ano, tempo esse suficiente para que as plantas pudessem realizar o seu ciclo biológico e revelar as modificações sofridas, em consequência dos fatores amblentals, notadamente a água com suas características quimicas, físicas e biologicas.

Os estudos limnológicos levados a efeito, entre nós, por KLEEREKOPER (1944), fornecem abundantes e preciosos dados sôbre as condiçб̃es biológicas da água, nas formas mals diversas. Particularmente interessantes, ao fim que tenho em vista, são as caracteristicas das correntezas. A propósito, escre.ve KLEEREKOPER (1944):

"A correnteza cria condiçð̃es ecológicas tão especiais que a biocenose dessas águas possul características morfologicos e fisiológicos inconfundiveis. esses característicos săo extraordinàriamente desenvolvidos em águas torrenciais como cascatas, cachoeiras, corredeiras, etc., enquanto em locais com menor correnteza tais característicos são menos pronunciados para desaparecer nos locais de correnteza mais fraca". (p. 141):

"A correnteza, em suas diversas intensidades, cria condiçôes tăo rudes para os organismos que habitam a água e seu leito, que adaptaçôes especiais săo necessárias para que esses organismos possam se manter em tais conđiçסes". (p. 142).

"As condições ecológcas da água de grande correnteza, de cachoeiras, corredeiras, etc., săo frequentemente analisadas na literatura. A significação da correnteza para os organismos encontrados nessas águas ainda năo foi descoberta. A quase totalidade desses organismos năo sobrevive em água de menor correnteza ou em água parada, mesmo quando um bom arejamento é garantido. Correnteza e agitaçăo causam contínuo arejamento da água onde o 
oxigenio e gás carbônico se encontram sempre em equilihrio com a tensăo desses gases no ar." (pp. 149-150).

As observaçōes que fiz, posteriormente, abrangendo o periodo de 14 de setembro de 1944 a 19 de junho de 1945 e que poderăo considerar-se complementares das que publiquei (ACCORSI 1944), vem confirmar as conclusరes a que cheguei sobre a blologia e a ecologia de tăo curlosas plantas, que : "levam um modo de vida peculiar, unico entre os Fanerógamos". (WILLIS 1945). Demais, outras aspectos do problema foram considerados e esclarecidos, tais como : o estado pastoso do rlzoma de Apinagia Accorsil e sua funçăo de substrato, destinado a retençáo das sementes e das plantinhas; a germinaçăo das sementes de ambas as espécles Apinagia Accorsii e Mniopsis Glazioviana no habitat; a regeneraçăo dos rizomas parcialmente dessecados de Apinagia Accorsii, quando em presença de con-. diçós favoráveis, além do papel dos estolhos, já assinalado na minha primeira contribuiçăo, quanto a propagaçăo vegetativa da espécle, etc., etc..

Os dados meteorológicos, constantes da tabela anexa, referem-se ao periodo de 1 de setembro de 1944 a 31 de dezembro do mesmo ano.

Na exposiçăo do assunto, segui a ordem cronológica das investigaçбes feitas no Salto. Para melhor interpretaçáo das morificaçóes morfológicas e compreensăo das fases de desenvolvimento das plantas em estudo, julguei conveniente relatar as condiçoes mesológicas vigentes na data de casa observaçăo.

Além das espécies citadas, vivem ainda, nas rochas diabásicas do Salto de Piracicaba, mais duas: Tristicha hypnoides (St. Hil.) Spreng. var. Hilarii Tul. e Mourera aspera. (Bong.) Tul.. A última fol encontrada em maio de 1944, por ocasióo de uma visita que realizei por tôda a regiáo do Salto, situada entre a ponte e a queda dágua. A distribuiçăo desta espécies circunscreve-se bem a montante da cachoelra, nas proximidades da ponte, onde chega a formar grupos compastos de grande número de individuos, incrustados as rochas. A Tristicha hypnoides, entretanto, tem uma distribuiçăo variável. De quando em vez, pequenas associaçoes de plantinhas eram encontradas sobre rochas dispostas em vários lugares como no declive, a jusante e mesmo a montante do Salto.

As espécies que têm ampla distribuiçăo local săo : Apinagia Accorsil Toledo e Mniopsis Glazioviana Warmg.. A primeira é dominante em toda a regiáo da queda dágua, 20 passo 
que a segunda se extende por tôdas as pedras, a montante da cachocira.

A familia Podostemonaceae está bem representada no Salto de Piracicaba, pois nêle medram quatro espécies de gêneros distintos. Tal ocorrência permite, ainda, fazer-se um estudo ecológico e biológico comparativo das espécies mencionadas, uma vez que todas se desenvolvem no mesmo habitat, de fácil acesso durante o periodo de vazante do rio e mesmo no inicio da fase de enchente. Todavia, no presente trabalho, ocupo-me, mais uma vez, das espécies Apinagia Accorsii Toledo e Mniopsis Glazioviana Warmg., principalmente da primeira.

As espécies Tristicha hypnoides e Mourera aspera serăo estudadas oportunamente, pois pretendo observar o seu comportamento biologico, em face dos fatores ecologicos, no decurso do ano de 1946.

II - DADOS PLUVIOMETRICOS DE 1 DE SETEMBRO DE 1944 ATE 31 DE DEZEMBRO DE 1944

\begin{tabular}{|c|r|r|r|r|c}
\hline méses & dias & chuva & duração & n.o de dias & média das médias \\
\hline setembro & $1-15$ & 5,2 & 4,30 & 3 & 22,0 \\
& $16-30$ & 8,1 & 4,20 & 2 & 23,6 \\
& & & & & \\
& $1-15$ & 49,6 & 3,50 & 2 & 26,7 \\
outubro ... & $16-31$ & 134,2 & 13,40 & 8 & 24,6 \\
& & & & & \\
& $1-15$ & 110,3 & 30,25 & 9 & 22,6 \\
& $16-30$ & 149,8 & 15,50 & 5 & 22,3 \\
& & & & & \\
dezembro . & $1-15$ & 148,9 & 21,25 & 4 & 23,7 \\
& $16-31$ & 9,8 & 5,35 & 4 & 26,1 \\
\hline
\end{tabular}

Dados fornecidos pelo Posto Meteorológico da E. S. A. "Luiz de Queiroz" - Piracicaba.

\section{III - APINAGIA ACCORSII TOLEDO}

\section{1 - Duração, regeneração e produções dos rizomas}

A 14 de setembro de 1944, o Salto de Piracicaba estava com as aguas baixas (pleno periodo de vazante), expondo avultada 
porcentagem de rochas à atmosfera (Figs. 1 e 2). Muitas plantas encontravam-se inteiramente a descoberto, de modo que poucos rizomas se conservavam vivos, justamente os que emergiram por último, com a descenção do nível dágua.

No leito do canal mais acessivel às observaçōes que costumo fazer, năo havia rizomas, embora as pedras se conservassem submersas. A razão de tal fato prende-se à redução do volume e da velocidade da água, que se tornou, por isso mesmo, pouco arejada; o referido canal passou a constituir simples corredeira, de condições ecológicas impróprias ao desenvolvimento de Apinagia Accorsii. Todavia, em pequenas gargantas naturais, onde a água conservou a velocidade e 0 arejamento (abundáncia de espuma) (Fig. 3), as rizomas continuavam vivos e em plena atividade vegetativa, comprovada pela produçáo de caules e de rizomas recém-formados (Fig. - 21 B, C, D, E, J, $\mathrm{K})$, ao lado de rizomas primitivos.

Em outros setores do Salto, de corredeiras mais rápidas e bem arejadas, o leito continuava atapetado de numerosas placas rizomáticas, algumas desprovidas de caules, mas com grande quantidade de gemas floriferas ainda fechadas, por se encontrarem submersas (Fig. 21-A,C). Das observaçōes feitas, resulta que a duração do sistema vegetativo de Apinagia está condicionada à velocidade, ao volume e ao arejamento da água porque, na mesma época e em locais do Salto bem próximos uns dos outros tém-se comportamentos distintos da mesma espécie, determinados pelos fatores ecológicos.

Nas faces verticais das grandes rochas, situadas no declive da cachoeira, e batidas por apreciável volume dágua bem arejada, assim como nas faces horizontais das que se dispunham a jusante do Salto, suportando a enorme pressáo da massa il quida (Fig. 4), havia notável quantidade de rizomas, dos quais pendiam longos caules, com cerca de $30 \mathrm{cms}$. de comprimento (Fig. 11). Os caules, como se vêem na fig. 11, são bem desenvolvidos; subdividem-se em secundários, terciários, etc., cujas extremidades se constituem de numerosas lacinias capiláceas. A haste principal, de forma ligeiramente cónia, apresenta-se encurvada, voltando-se a curvatura contra a correnteza. Na figura 21, os rizomas $B, C, D, E, I, J$ e $K$ mostram muito bem a curvaturn das caules; alguns, como $D, J$ e $K$ revelam gemas ramiferas, com disposiçăo alternada.

As plantas que permaneceram constantemente sob considerável volume de água, em boas condiçōes de velocidade e de arejamento, como sucede na zona da cachoeira, nada sofreram do ponto-de-vista vegetativo. Contudo, suas gemas floriferas 
năo chegaram a desabrochar, em consequéncia da açăo exercida pelo fator água.

Acresce que, em condiçóes favoráveis a.o desenvolvimento e ao crescimento, há, ainda, a possibilidade de se formarem novos rizomas a custa de pequenos fragmentos vivos de rizomas remanescentes, exparsos pelas rochas (Fig. 15-B). Tratase de um processo regenerativo, que visa assegurar a permanência da espécie no habitat. Anotei numerosas formaçбes de rebentos produzidos segundo o processo citado.

A regeneração das partes vegetativas, entre as Podostemonaceae, fol assinalada, também, por TOBLER (1933), que estudou, resumidamente, a blologia e a ecologia das espécies Mourera aspera (Bong) Tul., Lophogine arculifera Tul. et Wedd., Lophogine helicandra Tul., Mniopsis scaturiginum Mart. e Tristicha hypnoides. Tul. encontradas no Rio Guandu, Estado do Espirito Santo, Brasil, chegando a registrar a ocorrencia de algumas formas de regeneraçăo, tanto de crescimento lateral como emergencias de superficie, que foram interpretadas como aproveitamento de reaçరes traumáticas, para aumentar a superficie; dêste modo, elas revelariam na ontogenia as mesmas tendencias que regeram a filogenia.

Verifiquei, ainda, em rizomas que năo chegaram à dessecaçăo completa e que conservavam algumas partes vivas, a formaçăo de novos rebentos que se orientavam segundo a direção da correnteza. Os rebentos que năo submergiram apresentavam flores e frutos, fato êsse que vem confirmar que o desenvolvimento do ciclo floral se realiza fora da açăo do fator água.

Em 29 de setembro de 1944, na superficie horizontal de uma rocha, próximo a uma pequena queda dágua, havia numerosos rizomas que produziram rebentos (Fig. 15-B), os quais ostentavam caules e gemas floriferas, em pleno desenvolvimento, além de numerosas flores e frutos (Fig. 22-A,B,C,D,I). De permeio com essas produções vegetativas e florais, encontrei pequenos fragmentos de rizomas encurvados, com uma das extremidades dessecadas, enquanto a outra continuava a produzir brotcs, caules e gemas floriferas. Tratava-se, por conseguinte, da regeneração de partes de rizomas que, embora tivessem permanecido em contacto com a atmosfera, não perderam a faculdade regenerativa. Em outras rochas, cobertas de residuos rizomáticos desecados, anotei partes verdes e vivas, em plena atividade vegetativa, o que comprova ser a duraçăo das plantas dependente do fator água, uma vez satisfeitas as condiçбes de velocidade, arejamento e pressão. Em tais circunstâncias, numeroses fragmentos de rizomas vivos e banhados continua- 
mente se achávam em franco desenvolvimento vegetativo (Fig. 15).

\section{2 - Estolhos e sua função}

A par da regeneraçăo vegetativa dos rizomas (Fig. 15-B) devo recordar o importante papel que cabe aos estolhos, quanto a multiplicação do numero de individuos no habitat. Os estolhos são emitidos pelos rizomas primitivos. Såo orgáos hemicilindricos, estreitos e alongados, providos de uma goteira na face ventral (Fig. 15-E). A luz da goteira obstrui-se, aos poucos, devido ao acúmulo, por sedimentaçăo, de particulas terrosas trazidas pela água, as quais, agindo como cimento, concorrem para a fixaçăo dos estolhos na superficie das rochas (Fig. 15-E). Demais, a parede da goteira produz pelos unicelulares, longos, de membrana espessa, cuja funçăo é servir de órgáas de fixação.

Dos flancos dos estolhos e com disposiçăo alternada, orlginam-se rizomas, os quais, desde as primeiras fases de sua formaçáo, aderem à superfície das rochas (Fig. $15-A, C, D$, E). Convém ter em mente que os rizomas produzidos por via vegetativa, à custa dos estolhos, săo idênticos aos que provêm do desenvolvimento dos "seedlings" (Fig. $15-$ A, C, D, E; Fig. 18 - A, B, C.).

As gemas ramiferas dos rizomas novos desenvolven-se, rapidamente, em caules, que logo se orintam contra a direçăo da correnteza (Fig. 16 - A). Elas podem ser prontamente locallzadas, ao longo dos estolhos, na forma de pequenas protuberancias laterais (Fig. 15).

Alem das gemas ramiferas, os jovens rizomas produzem, no seio dos seus tecidos, as gemas floriferas que aguardam, apenas, condições favoráveis (exposiçáo ao ar) para entrar em desenvolvimento (Fig. 22 - E, F, G, H, M, N, O). Os rizomas eståo, por conseguinte, descle os primeiras estágios de sua formaçáo, capacitados, biologicamente, para enfrentar os meios água e ar, tăo indispensáveis ao desenvolvimento das Podostemonaceae. As duas fases, a vegetativa e a floral, estzo muito próximas, fisiologicamente. Aguardam, apenas, a açăo do melo ambiente para que uma ou outra entre em atividade.

Torna-se desnecessário, portanto, a fase vegetativa, atingir o estado adulto para entrar em atividade a fase floral, como sucede com a maioria das plantas fanerogamicas, porque ambas estão igualmente em condiçסes de agir, segundo o melo que vigorar na ocasiāo. Deve haver, pois, uma espécie de equilibrio fisiologico que pode pender para uma ou para outra das 
fases, conforme as condições ecológicas vigentes no habitat. Pelo fato de estarem em contacto com a atmosfera, alguns rizomas bem novos, que se achavam ligados ainda aos estolhos, revelavam flores e frutos, em vários graus de desenvolvimento. ao lado de caules jovens (Fig. $22-\mathbf{E}, \mathbf{F}, \mathbf{G}, \mathbf{H}, \mathbf{M}, \mathbf{N}, \mathbf{O}$ ). Aliás, os rizomas de plantas originárias de sementes revelam igual comportamento biológico. Tăo logo mudava a natureza do meio ambiente, as plantas paralisavam uma das fases para ativar a outra.

Essa adaptação é importantíssima para a garantia da espécie no habitat, de condições ecológicas relativamente variáveis, mormente em determinadas épocas do ano.

\section{3 - Dessecação dos rizomas}

A 10 de outubro de 1944, a sêca intensa ainda continuava. Havia mêses que nåo chovia regularmente. Nunca o Salto posà mostra tão grande quantidade de pedras (Fig. 5). Secaram muitos canais, inclusive os que traziam, em seu leito de pedra, rizomas já desprovidos de caules. Nas rochas expostas à atmosfera, só havia plantas dessecadas, ao lado de numerosas impressðes, contornos de rizomas. etc..

Sóbre algumas pedras existia, cêrca de vinte dias atrás, certa porcentagem de rizomas parcialmente expostos, a par de outros já em contacto com a atmosfera a que demonstravam reinicio de atividade vegetativa (Fig. 14). A 10 de outubro, entretanto, como persistisse a sêca, os rizomas vieram a morrer. Todavia, a quantidade de frutos era enorme. Apenas em poucos lugares, de correnteza mais atenuada, medravam rizomas, que ostentavam ainda seus caules.

A 17 de outubro de 1944, após o temporal desabado a 13 o da intensa chuva caida a 16, o nivel das águas do Salto elevouse o suficiente para banhar os rizomas que, até enţ̌o, permaneciam a descoberto. Contudo, dias depois, sendo novamente expostos à açăo direta do sol, tornaram a dessecar-se. Possivelmente, as camadas mais profundas dos rizomas que menos sofreram a açăo solar e a falta de água, continuavam vivas. Inúmeros rizomas com nova produçăo de caules e que náo ficaram totalmente fora dágua (prova de que a duraçáo das plantas é uma funçáo do fator correnteza), desenvolviam-se normalmente.

Resulta, pois, que os rizomas de Apinagia Accorsii, quando permanecem expostos à atmosfera, por multo tempo, como sucede durante o periodo de baixa do rio, sem receber umidade, 
acabam por dessecar-se e por transformar-se em placas duras. Ao contrário, se, durante o periodo de vazante, os rizomas forem convenientemente umidecidos, entåo se terá uma massa pastosa. Aste último estado do rizoma é favorável à fixaçăo e à germinaçáo das sementes.

As Podostemonaceae săo absolutamente incapazes ae viver em substrato arenoso ou lodoso, bem como em água parada. Fora do seu habitat, as plantas de Apinagia murcham, adquirem uma coloraçáo escura e secam completamente. Quando conservadas em água parada, decompóem-se logo.

\section{4 - Função dos frutos fixados nas rochas}

No dia 31 de outubro de 1944, devido às pesadas chuvas caidas, o nivel das águas elevou-se, outra vez. Quase tódas as rochas submergiram (Fig. 6). As poucas que ainda se expunham na atmosfera mostravam apenas agrupamentos de frutos, pois as rizomas morreram completamente, em consequencla da longa permanéncia ao sol; em seu lugar, permaneciam somente placas secas, de cór parda (Fig. 7). Estas que, dias atrás, continuavam incrustadas às rochas emersas, foram inteiramente eliminadas pela impetuosidade das águas (Fig. 8). Entretanto, milhares de frutos mantinham-se firmemente fixados as pedras, apesar de estarem sob forte correnteza. Seus pedicelos curvavam-se tanto que as cápsulas tangenciavam as rochas.

Como consequência final do ciclo biológico de Apinagia, no habitat, restam somente os frutos que continuam implantados ao substrato. extraordinàriamente notável que a fixaçăo seja tåo perfeita que permita aos frutos resistirem a enorme pressão da água e à intensissima vibração ocasionada pela correnteza, durante dias, semanas e até méses, a-fio. Em tais condiçōes, as sementes, para a propagação da espécie, só poderão encontrar meio favorável e adequado dentro das cápsulas fruliferas (ver o capitulo correspondente). A passagem das plantinhas para o substrato definitivo dar-se-á segundo o mecanismo já descrito (1). Dadas as condiçoes de enchente do Salto, em hipotese alguma as sementes poderiam permanecer no meio externo, porque seriam fatalmente arrastadas pela excessiva velocidade da água (ver fig 10)).

Exceto as pedras que, por sua situaçăo, estavam ainda revestidas de rizomas as demais revelavam somente frutos, em grande quantidade, porque a parte vegetativa se destruira inteiramente, devido à prolongada exposiçăo ao ar e ao sol. $O$ 
revestimento vegetativo dessas rochas só será possivel, a custa de plantas que provenham de sementes e isso no próprio local, devendo a germinaçăo realizar-se ùnicamente no interior das cápsulas, sóbre os pedicelos, de acordo com o mecanismo assinalado.

Encontrei, também, muitos frutos deitados sobre a rocha, por causa da flexibilidade do pedicelo, cujas cápsulas ostentavam plantinhas desenvolvidas, ao lado de grande número de individuos, em várias fases de desenvolvimento.

\section{5 - Rizoma em estado pastoso}

O rizoma, antes de dessecar-se, transforma-se em pasta. Mas, com a continua permanéncia ao sol, a pasta endurece, formando placas rijas. Entretanto, por causa das chuvas periódicas ou devido à variação do nivel dágua, o rizoma pode permanecer em estado pastoso e desempenhar importante papel no processo de fixaçăo dos pedicelos dos frutos sóbre as rochas. A massa rizomática constitui, ainda, excelente meio para a germinaçăo das sementes, conforme se verá mais adiante. Quanto maior fôr o grau de secação da massa rizomática, tanto mais firme será a fixaçăo dos pedicelos na rocha.

Em virtude da conformaçáo topográfica do Salto, encontravam-se rochas em tódas as posiçóes, quanto ao nível dágua, isto é, rochas submersas (em peueno número durante a séca), semi-expostas e expostas, cada qual com o revestimento vegetativo compativel com os fatores do meio ambiente. Portanto, havia rizomas verdes sem caules, mas com gemas floriferas (Fig. 13), rizomas em estado pastoso e rizomas completamente dessecados, reduzidos a placas sécas, com aspecto de líquens De acórdo com o grau de exposiçáo dos rizomas, na atmosfera, têm-se os diferentes estágios de florescimento e de frutificaçăo, pois as gemas floriferas só se desenvolvem e se abrem quando em contacto com a atmosfera.

Embora as águas lavem muito bem as rochas, principalmente durante a época de chuvas prolongadas como as que ocorrem no inicio das enchentes, fica sempre certa porção de substancia rizomática na base dos pedicelos dos frutos, em quantidade suficiente para promover a sua fixaçăo. Esta é tão perfeita que os frutos nåo se desprendem, mesmo quando submersos, seja qual for a velocidade da água, conforme pude verificar "In loco". 
6 - Germinação das sementes, fixação e desenvolvimento dos "seedlings" nos substratos

A perpetuação das plantas, através da germinação das sementes, tem sido assinalada, de modo geral, por todos quantos se dedicaram ao estudo da biologia das Podostemonaceae, como se processando sóbre as rochas em restos de "talos" velhos incrustados na sua superfície, conforme se depreende dos trabalhos de ENGLER (1930), WARMING (1882), WILLIS(1915 e 1926), RAUH (1937), etc.. Todavia, nenhum dêles faz menção a respeito da germinação das sementes sôbre as placentas, nas paredes internas e externas das cápsulas frutiferas, nos pedicelos, nas partes vegetativas, etc., etc.

A propósito da germinação das sementes e do desenvolvimento dos "seedlings", WILLIS (1902; segundo RAUH 1937, p. 422) assim descreve a espécie Lawia Ceylanica :

"As sementes sem tecido nutritivo germinam, imediatamente, quando umidecidas, sôbre pedras e restos de talos velhos. Há formação de dois cotilédones grandes e um hipocótilo grosso, que se fixa ao substrato por meio de pélos radiculares. Não há formação de radícula, por ser uma espécie que pertence ao grupo das Podostemonaceae que não têm raiz, em qualquer fase do desenvolvimento. $O$ hipocotilo forma depois um tubérculo que se transforma diretamente em caule taloso "shoot thallus", de crescimento plagiotrópico. Durante a primeira fase do crescimento ortotrópico, as fôlhas como também os cotilédones, sáo simétricas, aparecendo a assimetria na fase plagiotrópica, que se traduz, finalmente, por um dimorfismo.

$\mathrm{Na}$ margem do talo e no plano dos cotilédones, encontram-se grandes fôlhas ovais, ao passo que na superfície existem follhas pequenas e estreitas, localizadas em duas fileiras. Mais tarde, aparecem muitos ramos endógenos com internós curtíssimos, de modo que as fólhas estreitas e lineares são dispostas em roseta. Esses galhos são de estrutura radial, quando se desenvolvem na superfíc $e$ do talo, e, dorsiventral, quando na margem. As flores são marginais ou dispostas na superfície do talo, especialmente quando um dos brotos se transforma numa inflorescência. A natureza caulinar do talo torna-se clara com o estudo da ontogenia. $O$ aspecto da planta adulta é semelhante ao de Ceylanicum olivaceum, onde a ontogenia mostra ser o talo de origem radicular". 
Na minha primeira contribuiç̧̃o (ACCORSI 1944), relatei a ocorréncia de numerosos casos de sementes, de ambas as espécies, que germinaram nas partes dos frutos assinaladas; no preserte trabalho, apresento abundantes exemplos, que confirmam a hipótese de que a germinaçăo das sementes nas substratos citados, tais como: placentas (Figs. 23 e 24), parede. internas e externas das cápsulas frutiferas (Figs. 16, 17, 18, 20 e 25), pedicelos, etc., constitui o processo mals seguro para a garantia da espécie no habitat.

Durante a germinaçăo das sementes, o embriăo, que năo emite raiz principal, produz, à volta de tóda a extremidade do hipocctilo, enorme quantidade de pélos radiculares (Fig. 26 e 27), cuja função é servir de órgăos de fixaçăo.

scbre a fixaçăo das plantas nas pedras, assim se exprime WILLTS (1915) :

"A fixaçăo dạ flantas sóbre as rochas é feita por meio de pelos radiculares ou, mais frequentemente, por "haptera". " Estes săo ó:gãos adesivos especiais, provavelmente de natureza radicular, que aparecem geralmente como protuberáncias exógenas da raiz ou do caule e se curvam para a rocha, onde se fixam e se achatam, segregando uma substáncia viscosa".

Por meio dos pelos radiculares, os "seedlings" fixam-se 2.0 substrato, onde se desenvolvem e crescem ate que as plantinhas sejam transferidas para a rocha.

Em muitas placas rizomáticas providas de elevada quantidade de frutas, encontrei diversas cápsulas que sofreram a deiscencia. As sementes que foram retidas pelas placas cheearam a germinar. Procedendo ao exame do material colhido nesse local, constante de frutos e massa rizomática, verifiquel a existéncia de vários "seedlings" fixados às paredes externas e internas das cápsulas e (Figs. 16, 17 e 18), alguns, presos à massa rizomática. Esta tem se revelado excelente meio para a germinação das sementes, no habitat. A aderencla das semen-. te.s, a massa rizomática, e facilitada, sobremodo, pela configuraçăo sutilmente rugulosa da sua testa. Evidencia-se, assim, o papel que desempenha a massa dos rizomas em decompasiçáo.

Das numerosas observaçoes feitas, conclui-se que a germi-

\footnotetext{
"O têrmo "haptern" plural e "h?pteron" singular foi proposto por WARMING (\$).
} 
naçăo das sementes no habitat pode realizar-se nos seguintes substratos: placenta dos frutos, quando parcialmente deiscentes; paredes internas e externas das cápsulas e (Figs. 16, $17 \mathrm{e}$ 18), finalmente, a massa pastosa dos rizomas decompostos.

improvável que as sementes possam fixar-se às pedras nuas, conquanto de superficies rugosas e ásperas, devido às contínuas lavagens (Fig. 8) a que estăo submetidas, provocądas pelas correntezas e pelas chuvas.

WILLIS (1915), fazendo consideraçōes em tôrno da origem das Tristichaceae e Podostemonaceae, escreve o seguinte, a propósito das sementes :

"As sementes, com uma ou duas exceçōes entre as espécies mais modificadas das ordens, săo muito numerosas, diminutas, exalbuminadas, com o tegumento externo constituido de células que se tornam mucliaginosas em presença da água. Estão contidas em cápsulas que se abrem, unicamente, ao ar séco. Estas sementes săo singularmente mal adaptadas ao modo de vida que caracteriza estas familias. Elas caem sobre as rochas expostas e enxutas, nos primeiros dias da estaçáo séca, que, em muitas regiós, onde estas familias crescem, dura poucas semanas. Antes de findar-se a estaçăo de sêca, a grande maioria das sementes já terá sido levada pelo vento e, uma vez fora das rochas, a possibilidade de alcançarem um ponto conveniente para se fixar e crescer é pràticamente nula. Mas algumas sementes permanecem e, quando as águas sobem, o restante será arrastado por elas.

No caso das plantas de Hydrobium olivaceum ou Lawia zeylanica, que eu calculo produzir (onde crescem bem) de 20.000 a 30.000 sementes, em média, o número de "zeedlings" - ou rejuveniscimentos - que podem surgir é, raramente, pouco mais que dois ou três, às vezes dez c muitas vezes um ou mesmo nenhum. Năo fora a regeneraçন̃. do talo velho, tem-se a impressáo de que a sobrevivência de algumas das espécies altamente modificadas, como estas, seria problemática. Mesmo que as sementes cheguem * germinar, muitos dos "seedlings" săo lavados e julgo nơo ser muito exagêro dizer que, seis meses após a germinaçăo, cada planta máe estará, no geral, representada năo mais que por um ou dois novos individuos".

Das observaçס̃es que tenho feito sóbre a germinaçåo das sementes das especies Apinagia Accorsil e Mnionsis Glaziovia- 
na, nos substratos citados, isto é, cápsulas frutiferas (Figs. 16, 17,18 e 20), pedicelos, restos vegetativos, massa rizomática, etc., etc., cheguel à conclusão de que o número de plantas que se obtém por êsse modo, é bem maior do que o assinalado por WILLIS (1915), embora eu náo tenha procedido, ainda, a uma contagem para verificar qual a média de "seedlings" produzidos por planta. Todavia, na época da germinaçăo e durante todo o tempo em que venho estudando e observando o comportamento biológico e ecológico das Podostemonaceae citadas, a quantidade de "seedlings" que pude colher é suficientemente grande para garantir, por si só, a perpetuaçáo das espécies no habitat. Demais, na ocasiăo de sêcas prolongadas, quando grupos de rochas são totalmente expostos à atmosfera, por multas semanas, sob intensa açăo solar, a-ponto-de se destruir tóda a parte vegetativa, somente os frutos permanecem em sua superficie, de sorte que, no próximo periodo de enchente, as novas plantas só poderăo originar-se da germinaçáo das sementes. Segue-se, pois, que para as espécies citadas e principalmente a Apinagia Accorsii, que revela grande adeptaçăo ao meio água, năo existe aquêle perigo apontado por willis (1915), isto é, "năo fôra a regeneração do talo velho, tem-se a impressáo de que a sobrevivência de algumas espécies altamente modificadas, como estas, seria problemática".

\section{7 - Propagação das plantas por meio de sementes}

A propagação das espécies, por sementes, é tăo viável quanto qualquer dos processos vegetativos de multiplicaçăo como : estolhos, regeneração de rizomas (Apinagia) (Fig. 15); raizes com gemas que se desenvolvem em novas plantinhas (Mniopsis) (Fig. 19). Em condiçбes extremas de sêca, a propagação por sementes chega a constituir o único processo capaz de responder pela sorte da espécie no habitat, porque a parte vegetativa se destroi, inteiramente, permanecendo incrustados à:z rochas quentes e enchutas apenas os frutos que encerram, em sua maloria, sementes. Tive ocasiáo de observar grande número de rochas, que possuiam durante tóda a época de séca apenas frutos e que, após o periodo de enchente, se recobriram de rizomas.

A 6 de novembro de 1944, por falta de chuvas, o nivel das águas baixou, em relação ao apresentado em 31 de outubro, o que determinou a exposiçáo de elevada porcentagem de rochas e com elas as numerosos agrupamentos de frutos que se mantinham bem inclinados, devido à açáo da correnteza. Percebia- 
se, claramente, ter sido intenso o fenómeno de lavagem das rochas, enquanto permaneceram submersas, pois as residuos de rizomas antes existentes sóbre as pedras foram eliminados (Fig. 9). Nenhum rizoma novo se desenvolveu entre os numerosos agrupamentos de frutos. Contudo, a germinaçăo das sementes prosseguia, conforme ficou demonstrado pelo exame do abundante e excelente material colhido a 31 de outubro de 1944. Entretanto, as rochas que se encontravam sob a correnteza e que nåo chegaram a emergir totalmente, estavam cobertas de rizomas novos, formados por via vegetativa.

A 11 de novembro de 1944, o Salto encontrava-se, outra vez, bem cheio porque nos dias 5 e 6 chovera bastante. A fase de enchente estava em curso. Com poucas exceçóes, todas as rochas submergiram (Fig. 10). Sóbre algumas pedras, que ainda se conservavam expostas, havia somente frutos e em grande quantidade, uma vez que tôda a parte vegetativa se destruira.

Nos dias 2 e 3 de dezembro, choveu o dia todo. A grande maioria das rochas cobriu-se de um lençol dágua relativamente espêsso. Diversas pedras que, ao submergirem, só possuiam densos agrupamentos de frutos, revelavam, nesta data, abundantess formaçōes de Apinagia Accorsii, com as caules arqueados, estando a curvatura dirigida contra a correnteza; as extremidades dos ramúsculos conservavam ainda as lacinias capiláceas (Fig. 11 e Fig. 21 - B, D, E, J, K).

As pedras, que assinalei durante o periodo de baixa do rio e que estavam revestidas exclusivamente de numerosas associações de frutos, mostravam, na ocasiáo da observaçåo, elevado número de plantinhas situadas entre os pedicelos. $O$ farto material colhido nessas rochas revelou, ao binocular, a presença de numerosos "seedlings", em vários estágios de desenvolvimento. Alguns estavam fixados sóbre restos de riromas, em estado pastoso. Outros cresciam no interior das cápsulas frutiferas (Ver figs. 16, 17 e 18). Muitas plantinhas desenvolviam-se normalmente sóbre as pedras. A princípio, os restos de rizomas serviram para a fixaç5o dos pedicelos no substrato; mais tarde, com a absorção de água, transformaram-se em massa pastosa adequada à fixação e d germinaçăo das sementes. Dest'arte, os residuos dos rizomas desempenham importante papel no ciclo biológico de Apinagia Accorsil.

A 16 de dezembro de 1944, as águas do Salto baixaram de nivel, por falta de chuvas; por êsse motivo, muitas rochas emergiram, permitindo-me verificar a presença de novas plantas de Apinagia, nos lugares onde, primitivamente, so havia formações de frutos. Coletado e examinado o material, identifi- 
quei numerasos "seedlings" no interior das cápsulas, ao lado das plantinhas fixadas na pedra. Anotei ainda que a germinação das sementes ocorreu, em grande parte, no interior das cápsulas (Figs. 16, 17, 18 e 20).

Muitas sementes haviam germinado também nos residuos pastosos dos rizomas, acumulados ao redor dos pedicelos dos frutos. Ébvio que as sementes náo podiam aderir à superfície nua das rochas, embora estas apresentassem textura aniratuasa, pois, com a ascençăo do nivel dágua, as correntezas tornaram-se extremamente intensas (Fig. 6).

1 perpetuação da espécie, nesse caso, só é possivel e viável a custa de sementes que germinaram no interior das cápsulas, no substrato pastoso (residuos de rizomas) e, ainda, na superficie dos rizomas.

Do exposto, fica definitivamente demonstrado o processo de propagação por sementes das espécies Apinagia Accorsii (Figs. 16, 17 e 18) e Mniopsis Glazioviana (Fig. 20), no habitat. As espécies Mourera aspera e Tristicha hypnoides serăo encara(las, sob o mesmo prisma, nas próximas observações.

\section{8 - Disseminação das sementes no habitat}

De permeio com os restos pastosos de rizomas de Apinagia, cresciam numerosos "seedlings" de Mniopsis Glazoviana, conquanto năo existissem, nas imediaçōes, frutos desta espécie. Esse fato prova a possibilidade do transporte das pequeninas sementes pela água ou pelo vento que, às vezes, se torna relativamente forte, no Salto. Os pássaros, que normalmente frequentam a cachoeira, à procura de insetos e de larvas de borrachudo (Simulium spp.) etc., para a sua alimentaçăo, constituem, possivelmente, outros fatores de disseminaçăo das sementes, pois larvas e casulos de borrachudo săo encontrados aos nillhares sóbre rizomas, caules, ramúsculos, flores e frutos de Apinagia, bem como em plantinhas de Mniopsis e de Trisiicha, de sorte que é bem provàvel que frutas e sementes sejam comitos por eles e, posteriormente, eliminados com as dejeções. Fstas se encontram em quantidade apreciável sobre as pedra.s. Resta, todavia, para se ter certeza, verificar se existem sementes ou mesmo frutos nesses residuos. 0 que pretendo fazer.

Dos pássaros mais comuns que visitam o Salto de Piracicaba pude registrar os seguintes: Bem-Te-Vi (Pitangus sutphuratus maximiliani), Martim Pescador ou Pica-peixe (Megacervle torquata), Andorinha Grande ou Taperá (Progne cha- 
lybea domestica). Esta última espécie, segundo IHERING (1940), é única e exclusivamente entomófaga, necessitando de 60 a 80 insetos para a sua refeição diária. Demais, as pequeninas sementes e mesmo as cápsulas poderiam ser retiradas pelas patas dos pássaros, ao pousarem sôbre as plantas.

\section{9 - Desenvolvimento das plantas durante o período de enchente}

A primeiro de janeiro de 1945 , visitei o Salto, cujas águas estavam tão baixas como nos dias de vazante. Havia dias que năo chovia. Como consequéncia, avultado número de rochas emergiu, exibindo notável desenvolvimento vegetativo, bem como a distribuição local das plantas de Apinagia Acorsii e de Mniopsis Glazioviana realizados durante o periodo de submersão. Em virtude de tal exposição, muitas plantas novas morreram, por causa da dessecação que sofreram. Entretanto, havia ainda frutos fechados sôbre as rochas, de maneira que a propagação da espécie, por sementes, estava garantida. Essa observação se aplicava igualmente à espécie Mniopsis Glazioviana.

\section{0 - Desprendimento dos caules}

E durante o período de submersão que os rizomas de Apinagia produzem os seus caules, os quais podem atingir até 30 cms. de comprimento.

A permanência dos caules sôbre os rizomas depende do volume e da velocidade da água. Decorrido certo tempo, variável com as características da correnteza, os caules desprendem-se ou se partem, segundo a intensidade das vibrações a que estiveram submetidos. Conforme o local onde se desenvolveram, os rizomas, antes de emergir, podem perder oul cons?i.var os seus caules. Em trechos do Salto, de correnteza atenuada, era comum a presença de rizomas ostentando caules, que não chegavam a se destacar, embora fossem posteriormente expostos ao ar; nestas condições, os caules persistiam dessecados. Todavia, os rizomas, que se desenvolviam em lugares batidos por forte correnteza, por muito tempo, acabavam perdendo seus caules, porque não resistiam às suas vibraçōes.

Os caules podem destacar-se, à superfície do rizoma, ficando, em seu lugar, as cicatrizes (Fig. $22-\mathrm{A}, \mathrm{B}, \mathrm{I}, \mathrm{J}, \mathrm{K}$ ); outras vêzes, a dilaceração dos tecidos (traumatismo) ocorre ao longo da haste, em extensão e nivel variáveis (Fig. $21-\mathrm{A}$, C, F, G, H, I). Para detalhes sôbre o assunto, ver ACCORSI (1944). 
11 - Estado geral do desenvolvimento das plantas, durante o período de vazante

A 8 de maio de 1945, as águas começaram a declinar de volume. O periodo de baixa do rio já se iniciara. Sua duração se estenderá, provàvelmente, até fins de setembro e mesmo mais tarde, conforme o regime de chuvas que vigorou.

O aspecto geral do Salto era bastante variado, revelando rochas em todos os níveis e posições, quanto ao meio água. Confrontei atentamente o comportamento das plantas de Apinagia, em relação ao fator água e suas condições ecologicas, em tôda a região da cachoeira. Assim, os rizomas de algumaśs plantas recém expostas à atmosfera e que já não possuiam caules mostravam desenvolvimento de gemas floriferas (Fig. 12); outros estavam com produção de frutos, ao lado de muitos rizomas em diversos graus de dessecação, segundo o tempo de permanência das plantas ao contacto do ar. Havia, por conseguinte, no Salto e, na mesma época, porém, nos mais diversos meios, plantas em vários estágios evolutivos, como reflexo da ação dos fatores ecológicos, destacando-se, em primeira plana, a correnteza. E evidente que houve necessidade de as plantas permanecerem submersas durante certo tempo - período de enchente - para que se realizasse o seu desenvolvimento vegetativo; todavia, as plantas jovens podem, antes de atingir o estado adulto, acelerar o seu ciclo biológico, produzindo flores e frutos, conforme os numerosos e excelentes exemplos encontrados durante as detalhadas observações feitas "in loco".

A espécie Mniopsis Glazioviana achava-se, nessa ocasiăo, em franco período de desenvolvimento vegetativo e floral. Seu ciclo biológico se processou paralelamente ao de Apinagia.

Penso que o comportamento biológico das Podostemonaceae que vivem no mesmo habitat se realiza de modo semelhante, respeitadas naturalmente as caracteristicas especificas. o que pretendo verificar no Salto de Piracicaba. Mais tarde, compararei os resultados a que cheguei com aquéles que serão obtidos do estudo das espécies que se desenvolvem em outras czchoeiras do Estado de São Paulo.

Quanto à espécie Mniopsis Glazioviana, nada tenho que acrescentar às observações gerais consignadas na minha primeira contribuição (ACCORSI 1944).

A partir de 19 de junho de 1945, choveu tão intensamente em Piracicaba, durante vários dias, que o nível do rio subiu ràpidamente para mais de dois metros, submergindo tôdas as rochas da cachoeira. O Salto apresentava-se como nos dias de 
enchente. Ocorrência Idêntica registrou-se há 29 anos, segundo informares que obtive. As Podostemonaceae encontravamse, por ocasiáo dessa enchente esporádica, em diversas fases de desenvolvimento tanto vegetativo como floral, de acórdo com o local.

f evidente que tal variação nas condiçóes mesológicas e surgida de modo inesperado, em pleno periodo de seca, devesse acelerar o ciclo vegetativo, em detrimento do ciclo floral, porque um e outro exigem para o seu desenvolvimento melos apropriados e fundamentalmente opostos. Com a baixa posterior to nivel dágua, entretanto, restabeleceram-se as condiçoes mesológicas primitivas, isto é, vigentes durante o periodo de séca, de sorte que as plantas reiniciaram as suas atividades normais.

Registro, abaixo, os dados pluviométricos do periodo anormal ocorrido entre 18 de junho e 7 de julho de 1945.

\begin{tabular}{|c|c|c|c|}
\hline \multicolumn{2}{|c|}{ JUNHO } & \multicolumn{2}{|c|}{ JULHO } \\
\hline Dias & Chuvas & Dias & Chuvas \\
\hline $\begin{array}{l}18 \\
19 \\
20 \\
21 \\
23 \\
24 \\
25 \\
26\end{array}$ & $\begin{array}{r}1,1 \\
0,1 \\
28,9 \\
77,7 \\
26,5 \\
31,2 \\
18,1 \\
2,3\end{array}$ & $\begin{array}{l}4 \\
5 \\
6 \\
7\end{array}$ & $\begin{array}{r}0,4 \\
24,2 \\
2,4 \\
2,6\end{array}$ \\
\hline
\end{tabular}

\section{IV - RESUMO E CONCLUSOES}

Resumindo as observações feitas sóbre a biologia e a ecologia das espécies Apinagia Accorsii Toledo e Mniopsis Glazioviana Warmg., Podostemonaceae que vivem incrustadas às rochas diabásicas do Salto de Piracicaba, durante os anos de 1943, 1944 e 1945, cheguel às conclusões seguintes :

a) Com o início do período de enchente do Salto de Piracicaba, variável de ano para ano, mas que, no geral, começa com as primeiras chuvas de outubro e se prolonga até fins de março, processa-se o desenvolvimento vegetativo das Podostemonaceae, com a formaçăo de estolhos (Fig. 15-B) dotados de gemas produtoras de novos rizomas (Fig. 16-A,C,D,E) e regeneraçáo dos rizomas primitivos (Fig. 15-B), quando em determinadas condiçōes, em Apinagia Accorsii; raizes hemicilindri- 
cas com produçס̃es faliáceas, dispostas aos pares. (Fig. 19-A,B, C,D,E,F,G,H), provenientes de gemas, em Mniopsis Glazioviana. Demais, em ambas as espécies realiza-se ainda a germinação das sementes nos seguintes substratos: placentas, cápsulas e pedicelos de frutos (Figs. 16, 17, 18 e 20), residuos orgánicos de várias procedencias, inclusive os provenientes das próprias P.2dostemonaceae, que se acumulam em quantidade apreciável entre as plantas e sóbre as rochas, etc. A Apinagia Accorsii, além desses meios, conta ainda com os residuos rizomáticos, com os caules e mesmo com a superficies dos rizomas (Fig. 21-H). A massa rizomática constitui excelente meio para a retenção = germinaçăo das sementes.

b) A deiscência dos frutos dá-se ao contacto do ar séco. As sementes podem fixar-se aos substratos citados, devido à transformação do tegumento externo em mucilagem.

c) Dentre os substratos para a germinação das sementes, o mais importante e mesmo decisivo, em determinadas circunstâncias, para a garantia da espécie no habitat, é o fruto. Após a dejscência, algumas sementes podem colar-se às paredes internas da cápsula e aos pedicelos, graças à mucilagem do tegumento externo, ao passo que outras permanecem sóbre a placenta.

d) Os "seedlings" năo apresentam raiz principal. Todavia, à volta de tóda a extremidade do hipocótilo, produz-se enorme quantidade de pélos radiculares, cuja principal funçäo é servir de órgăos de fixaçăo. A incrustação das plantas ao substra. to é feita por meio de pélos radiculares, ou, mais frequentementr, por "haptera". Segundo WILLIS (1915), "os "haptera" săo orgăos adesivos especiais, provàvelmente de natureza radicular, que aparecem como protuberáncia exógenas da raiz ou do caule e se curvam para a rocha, onde se fixam e se achatam. segregando uma substáncia viscosa".

e) Os "seedlings", que se desenvolvem sóbre as cápsulas, pedicelos, etc., encontrando condições ecolç?icas favoráveis, transformam-se rápidamente em plantas jovens; os novos rizomas já começam a produzir caules e em tudo se assemelham aos rizomas provenientes dos estolhos. 0 que se observa no habitat, por ocasiąo da germinação das sementes.

f) As transferencia das plantinhas, que so desenvolvem no"; substratos citados para a superficie da rocha, realiza-se quando elas alcançarem o peso suficiente para curvar o pedicelo do fruto. (Figs. 17 e 18), promovendo, assim, o contacto da cápsula com a rocha. Dal por diante, o novo rizoma vai aderindo an substrato natural, através da produçáo dos órgáos especiais de fixaçăo, isto é, pelos radiculares e "haptera". O mecanismo da 
Devido a um pequeno engano na feitura dos clichés, os aumentos das figuras 15, 16, 19 e 20 , constantes da legenda, passarão a ser respectivamente :$1,9-1,65-2,3$ e 2,9 . 


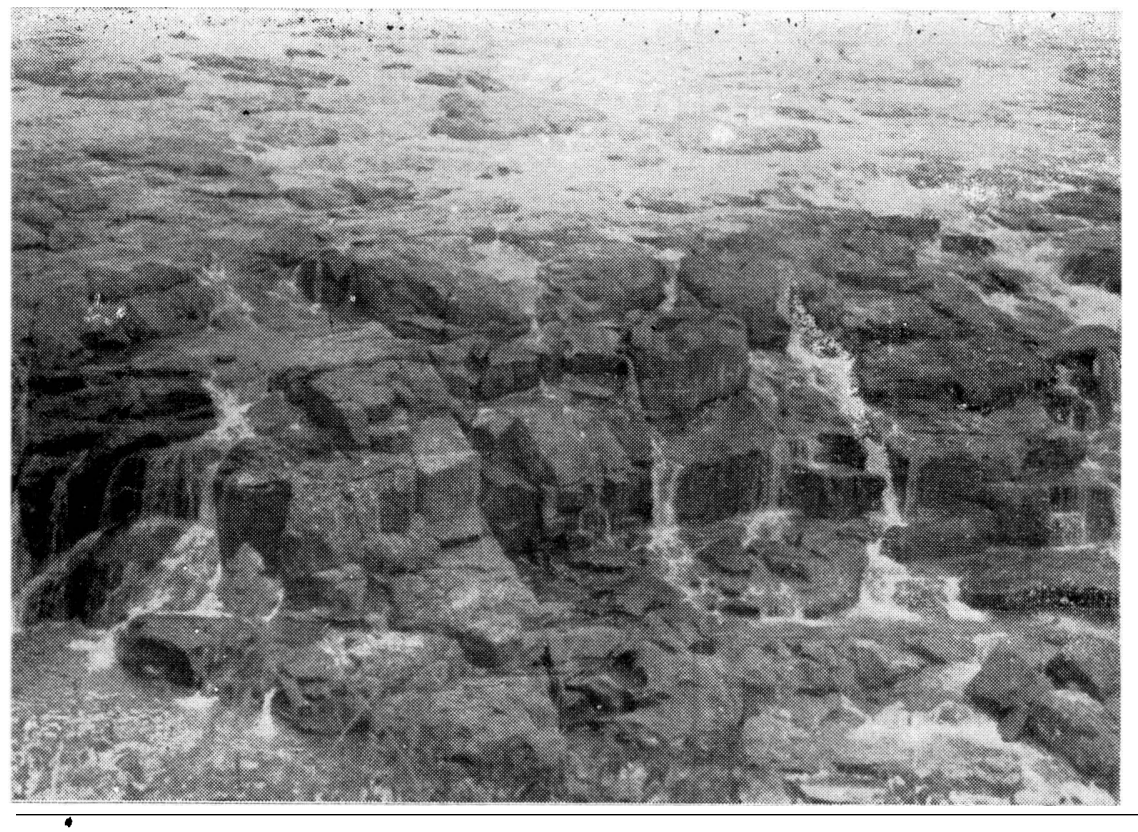

Fig. 1

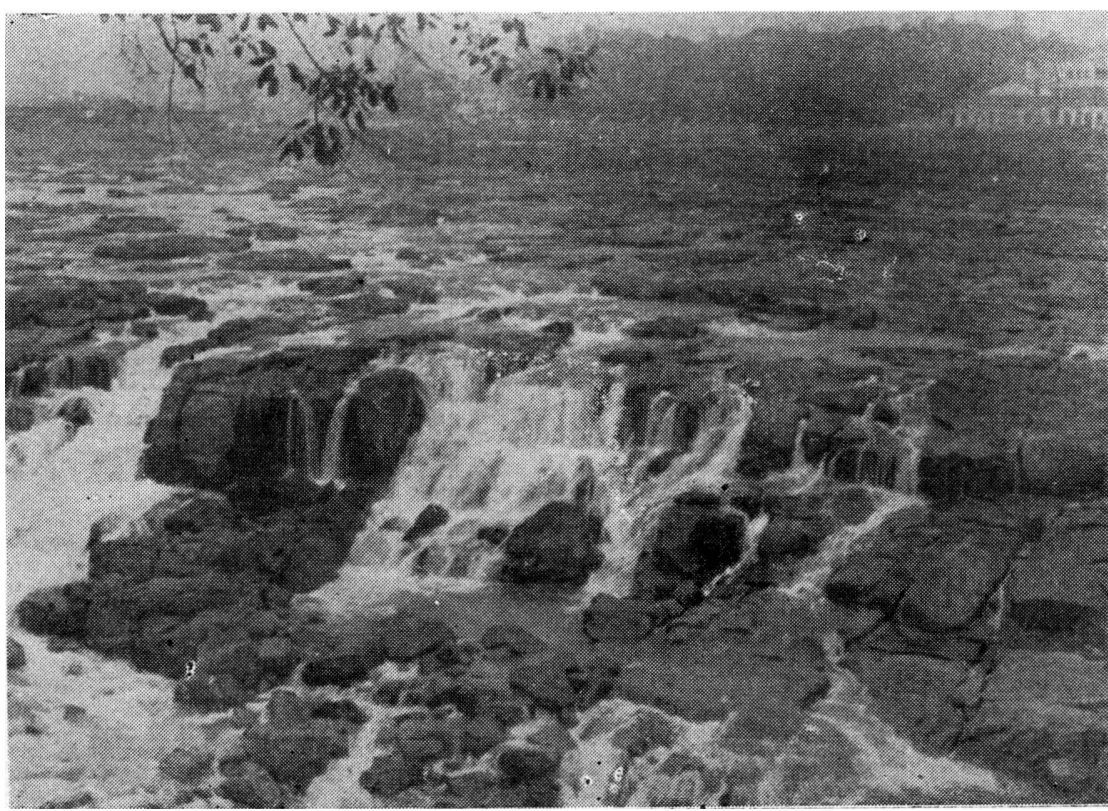

Fig. 2 


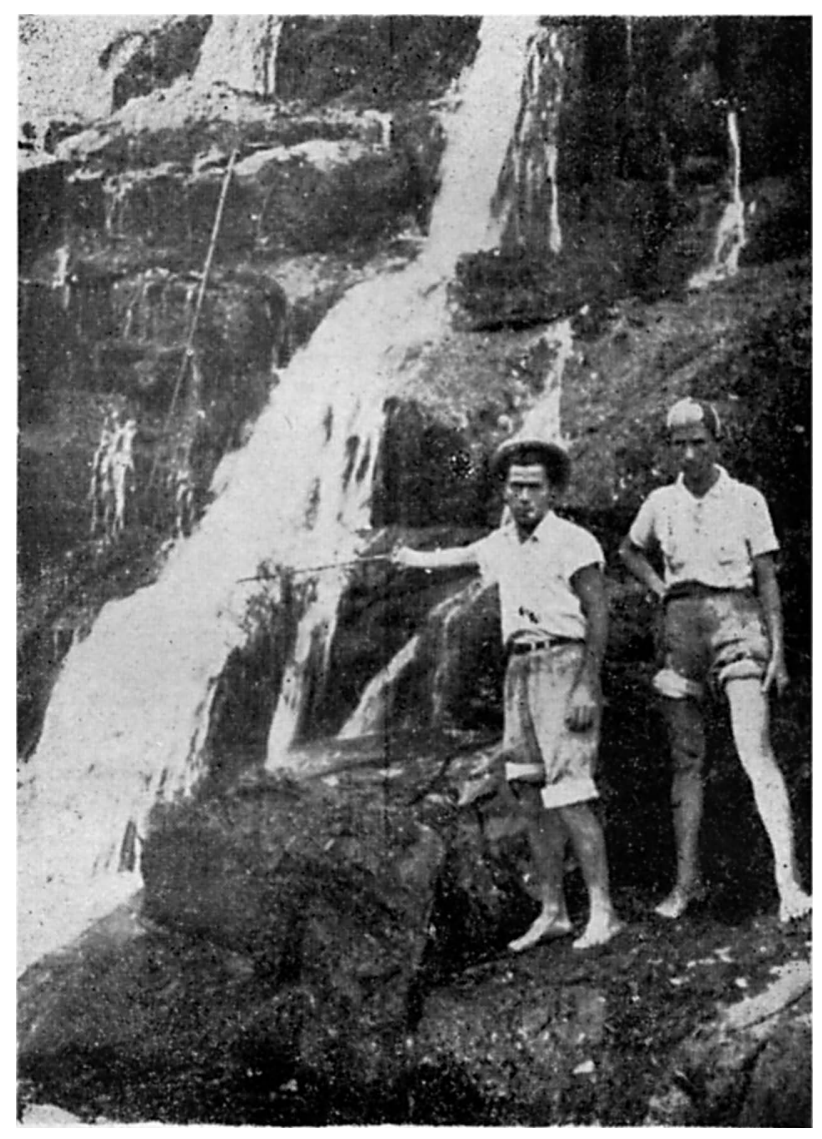

Fig. 3 


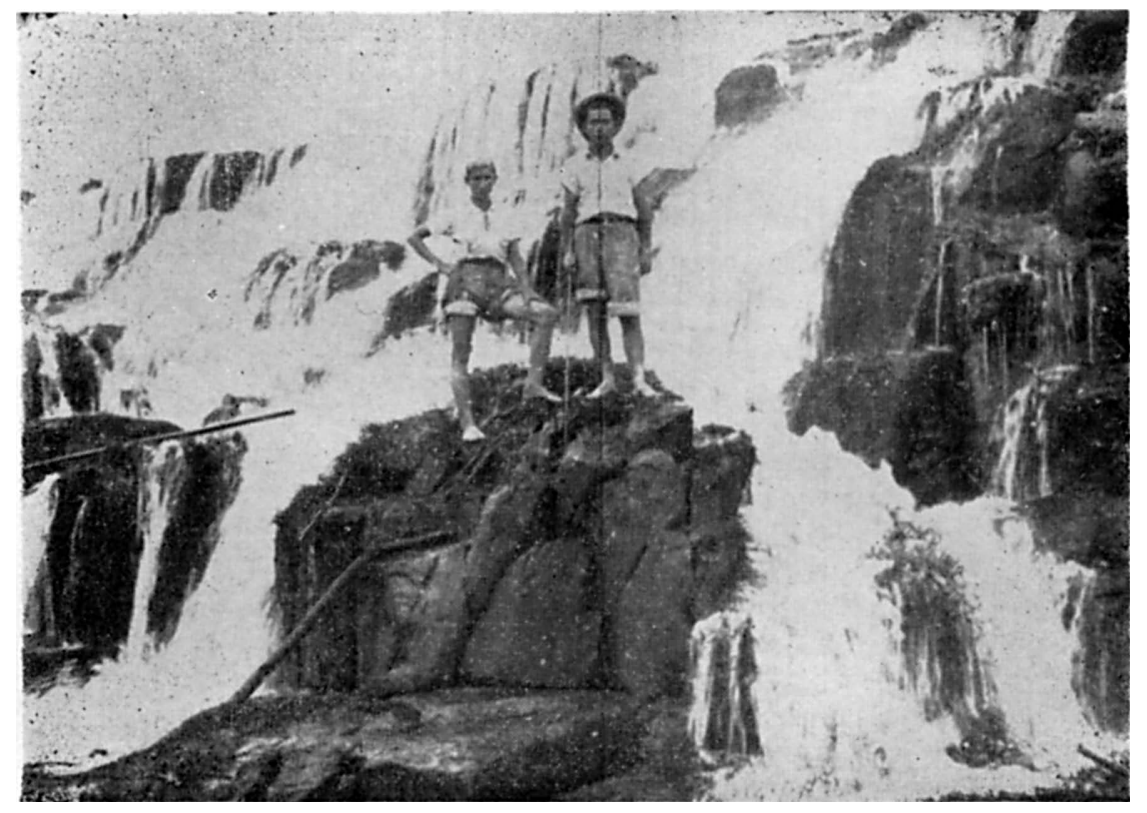

Fig. 4

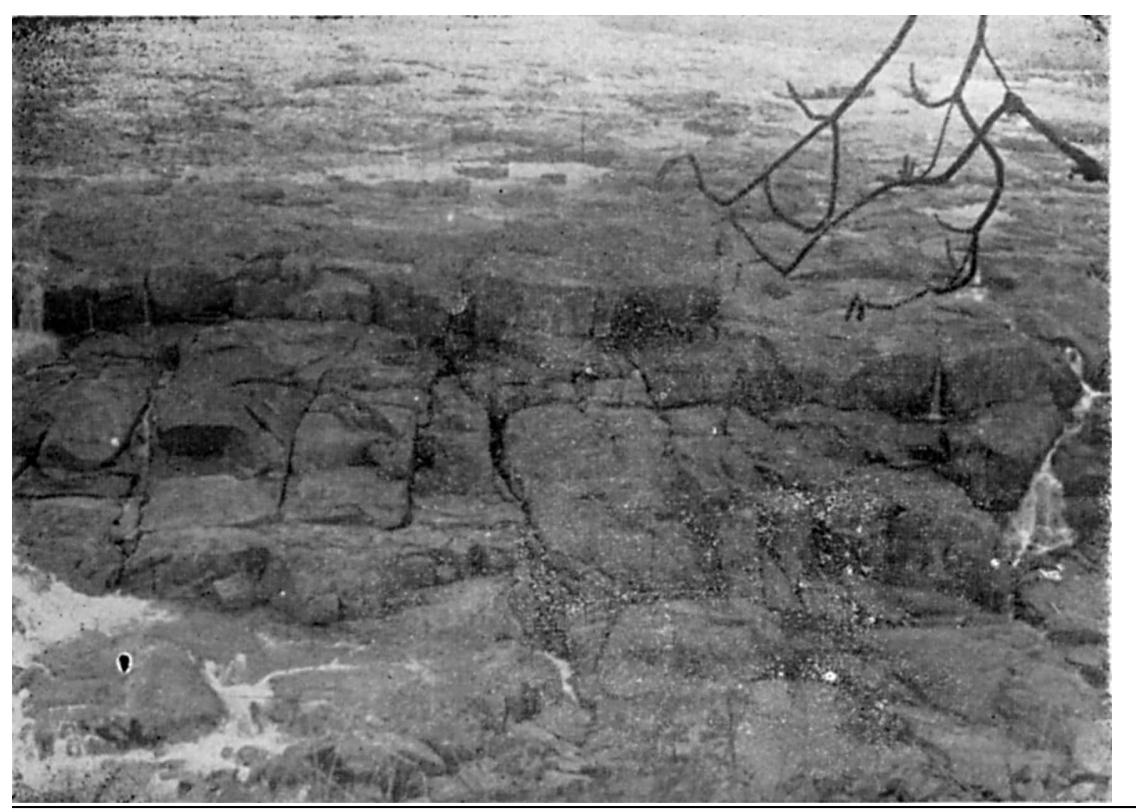

Fig. 5 


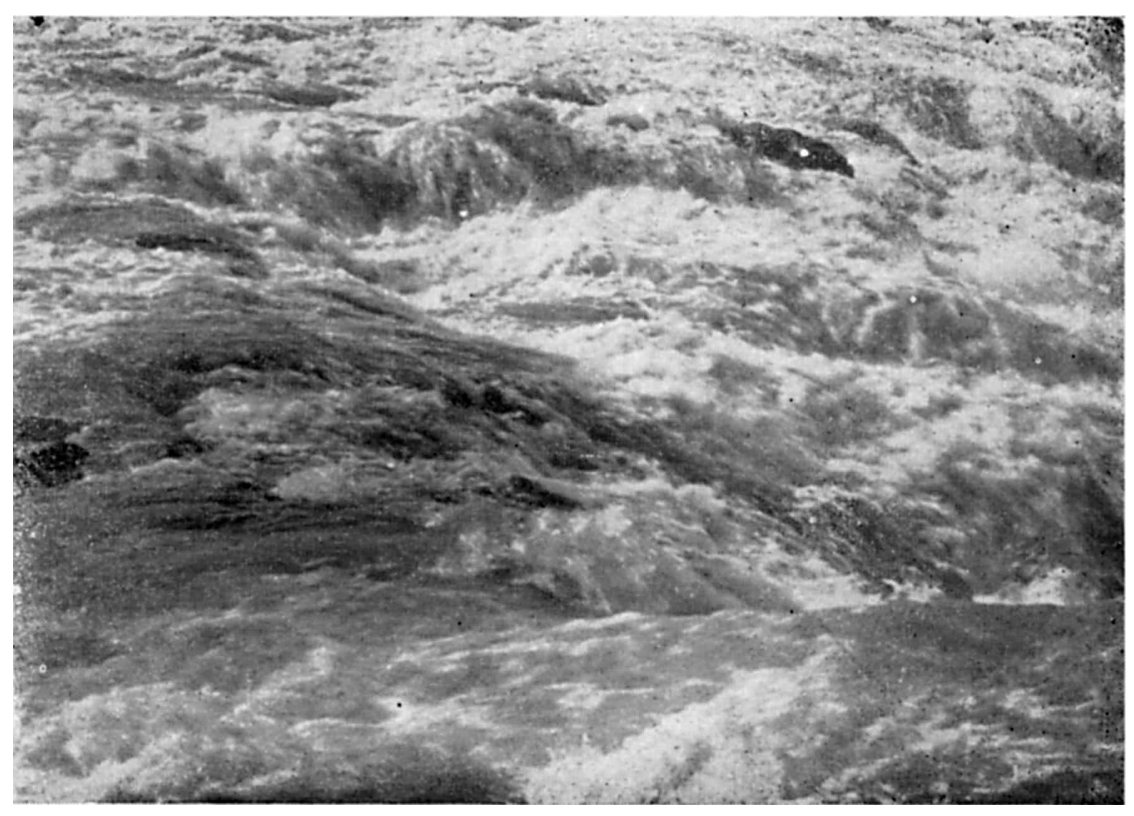

Fig. 6 

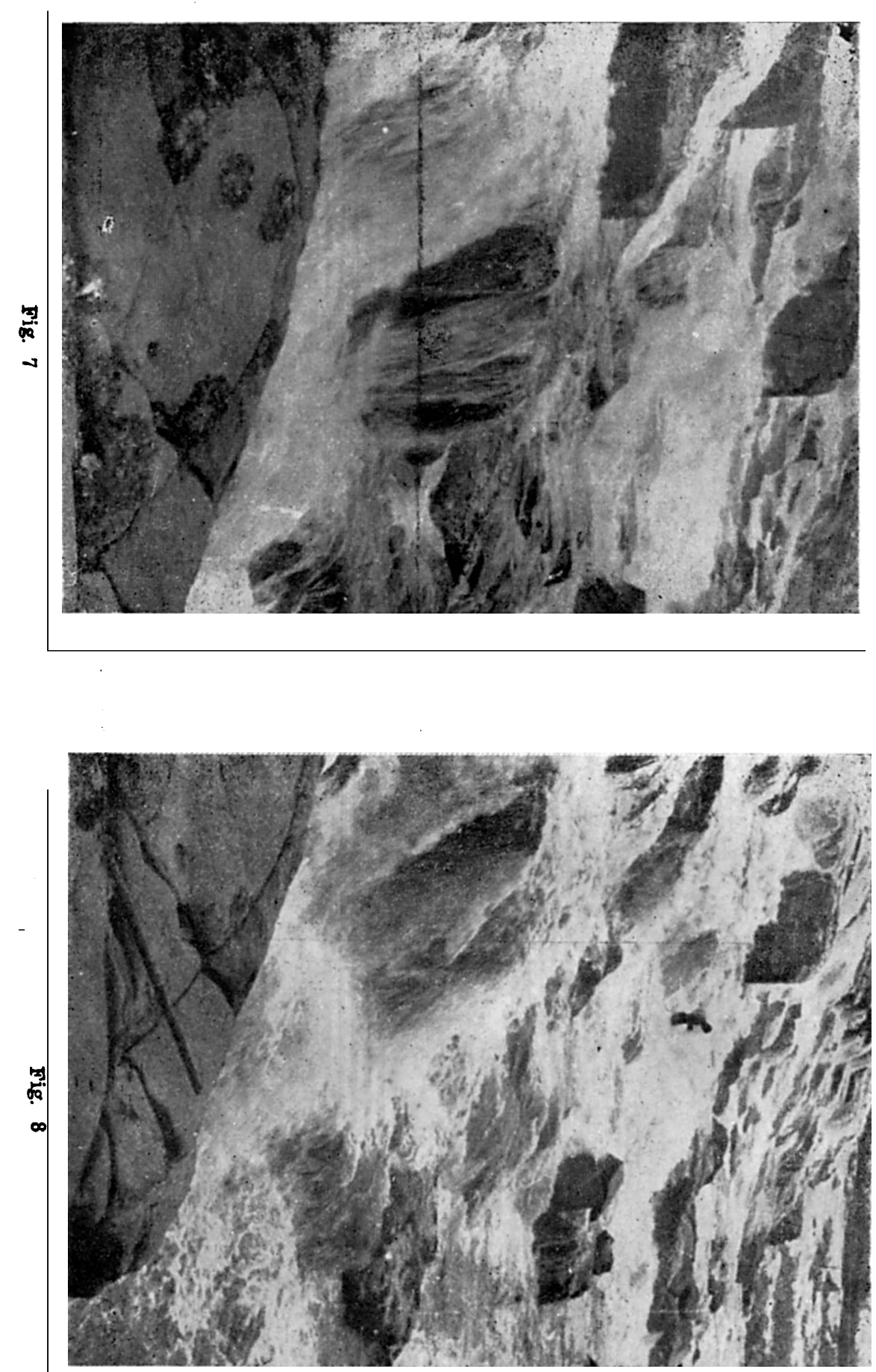


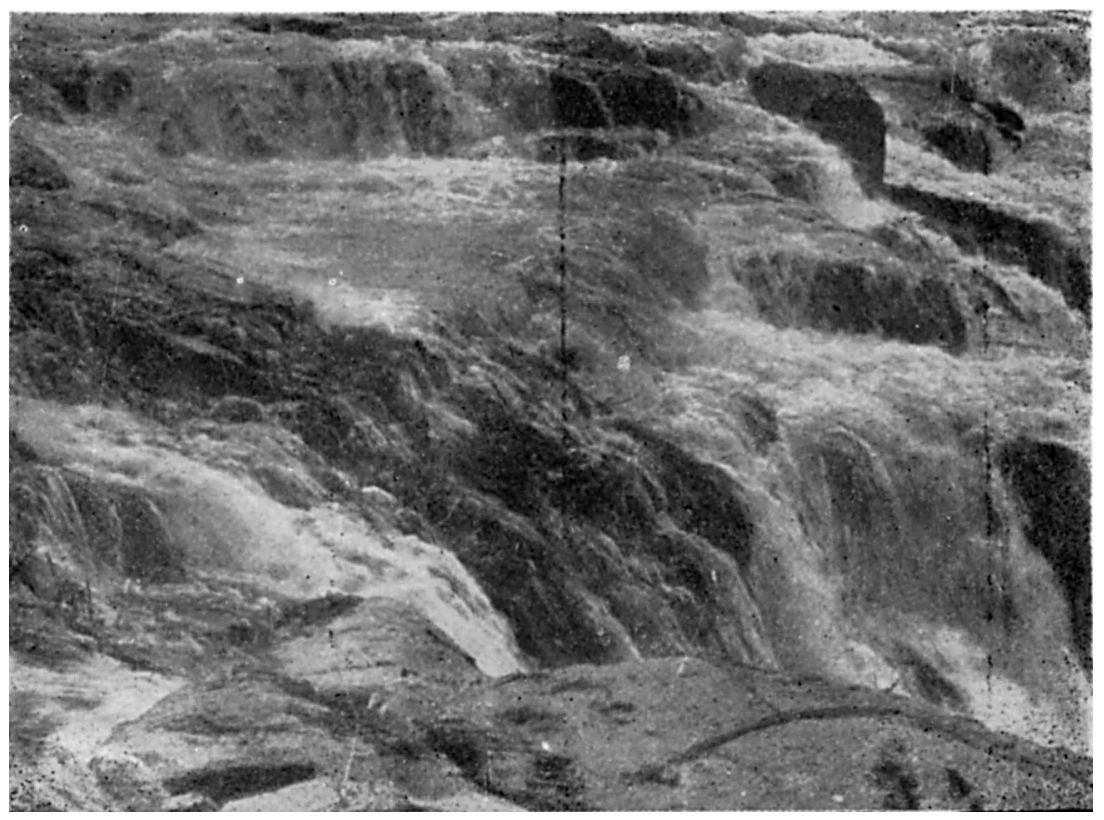

Fig. 9

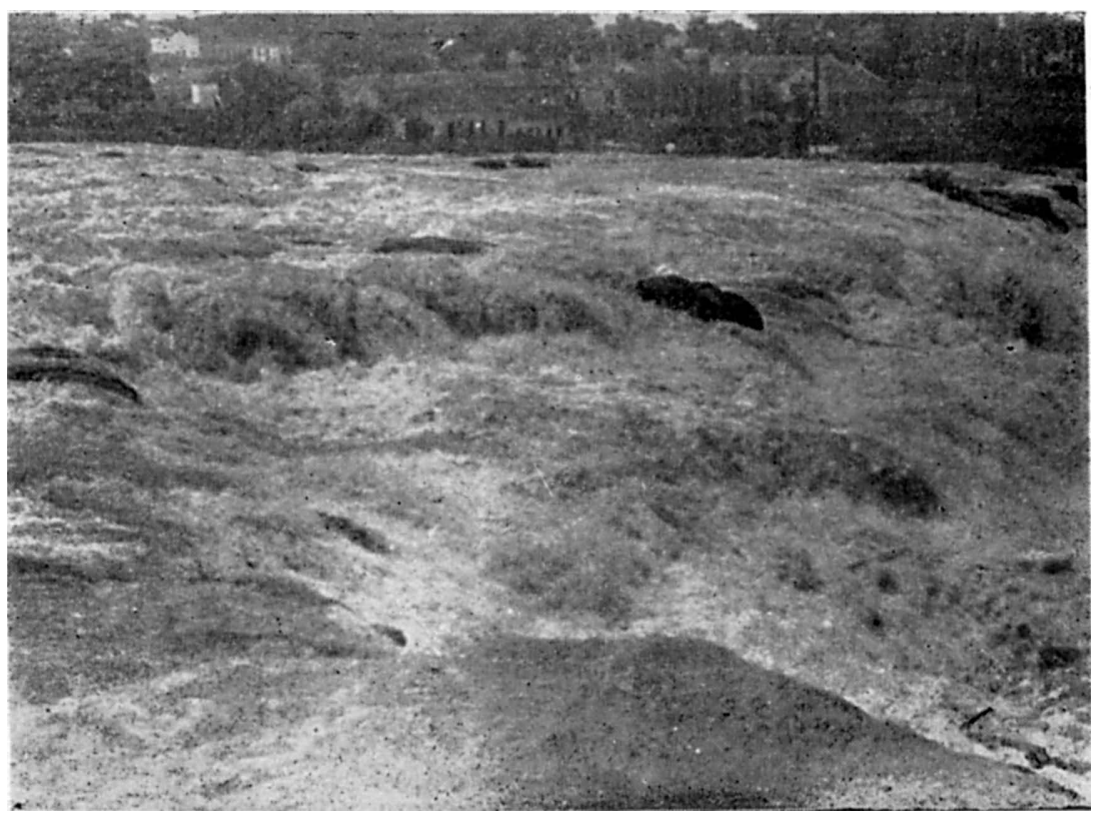




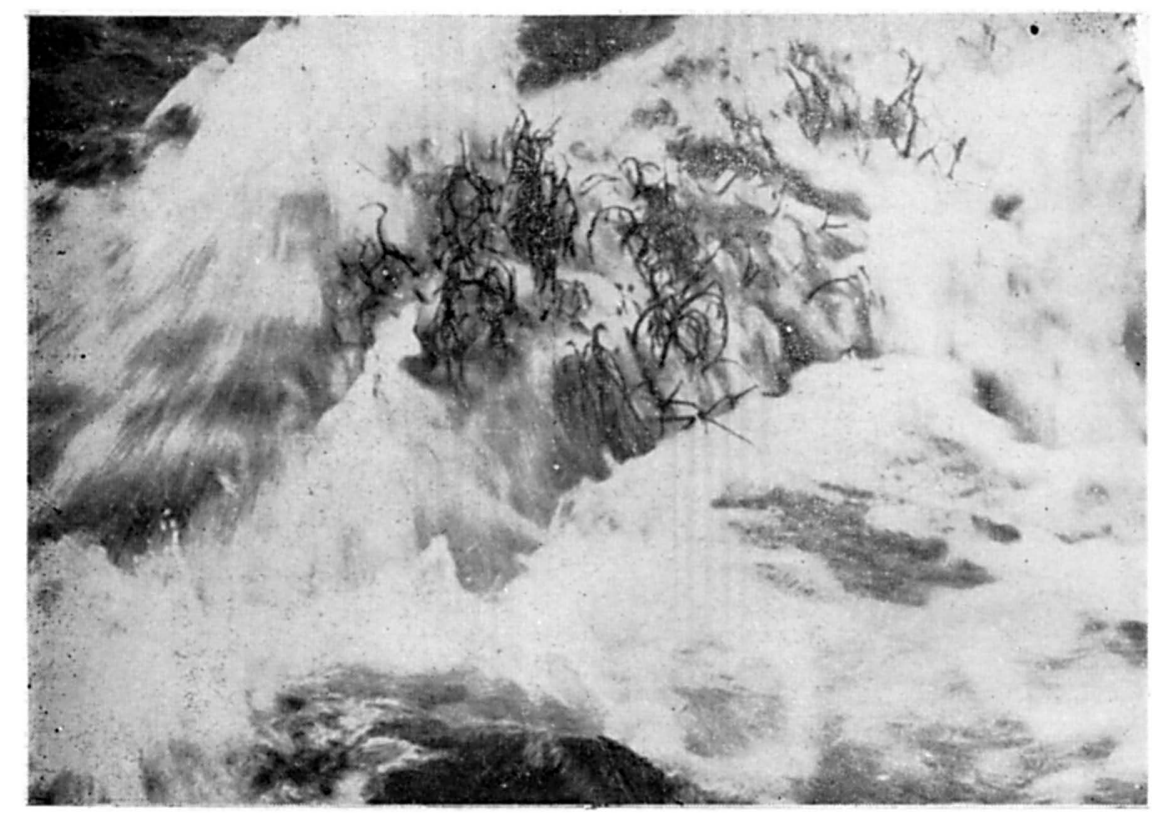

팇. 11

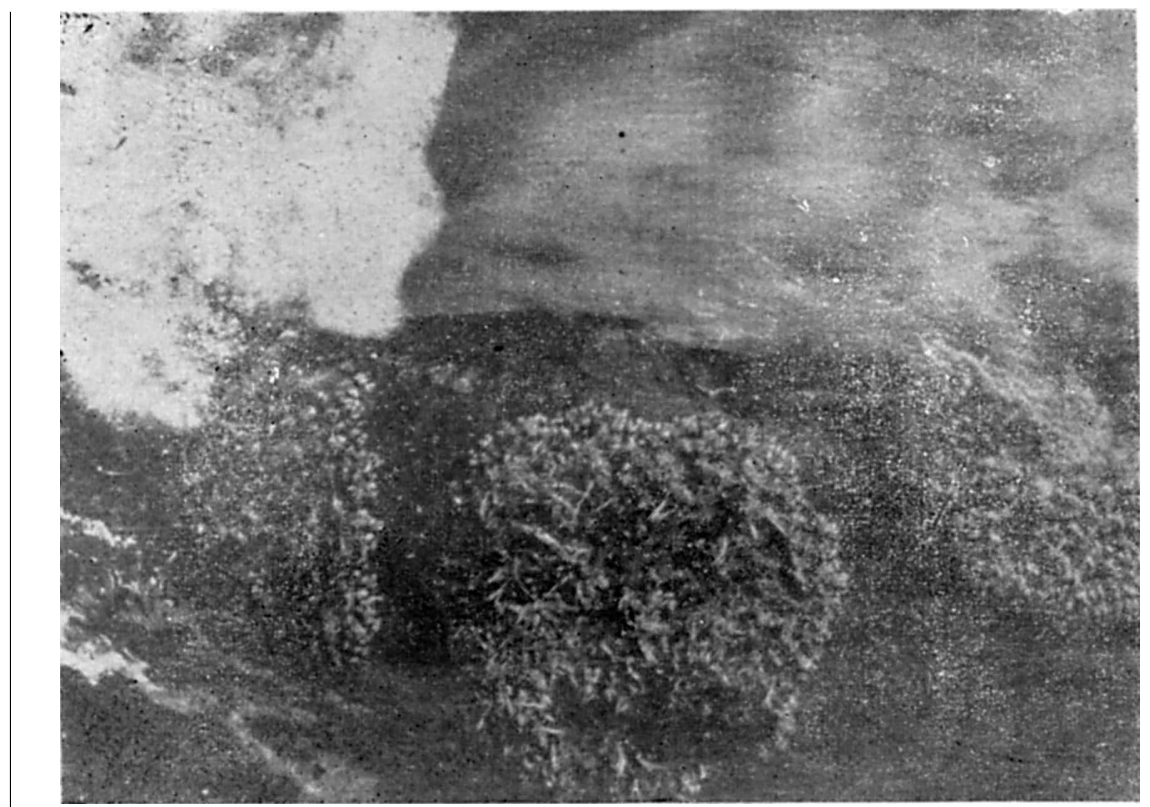

Fig. 12 


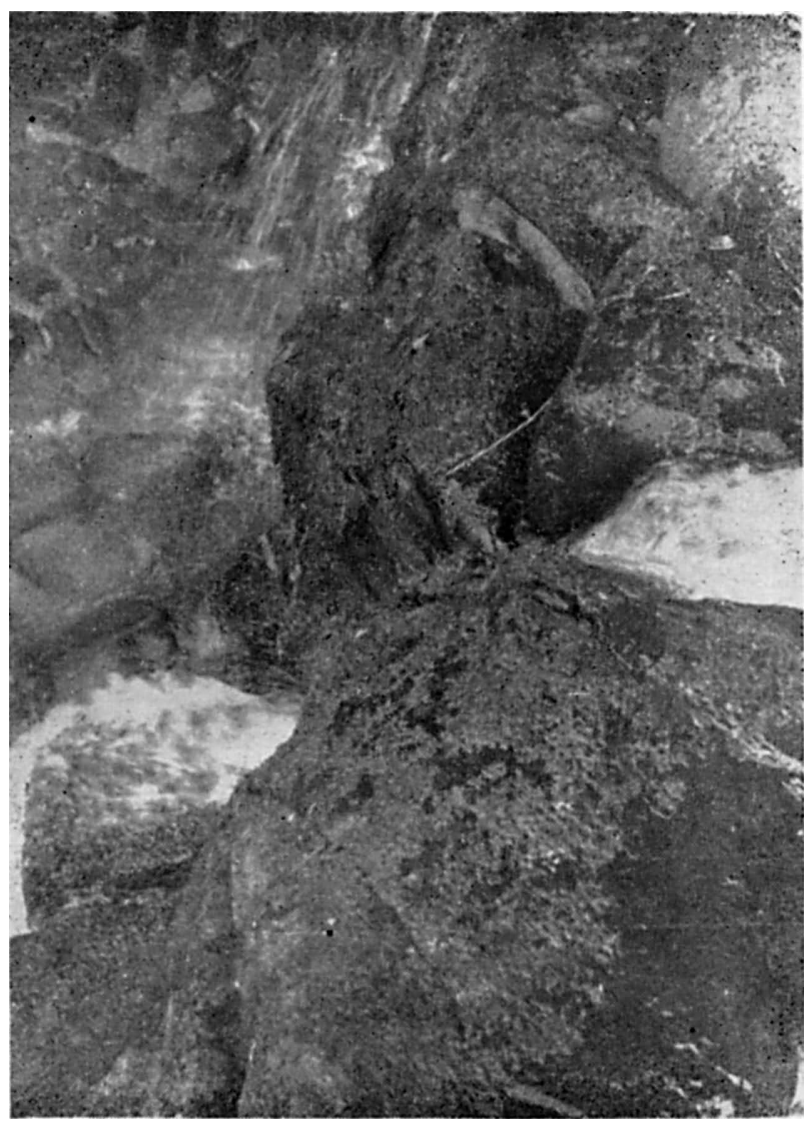

Fig. 13 


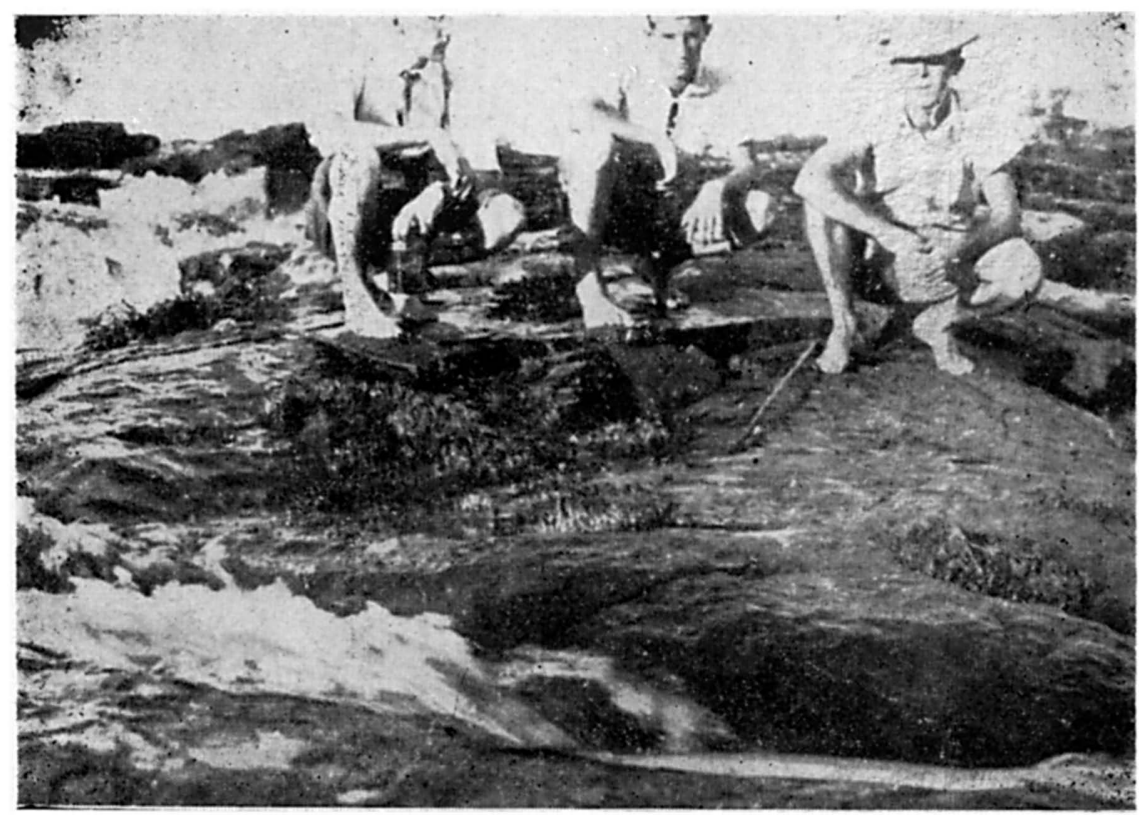

Fig. 14 


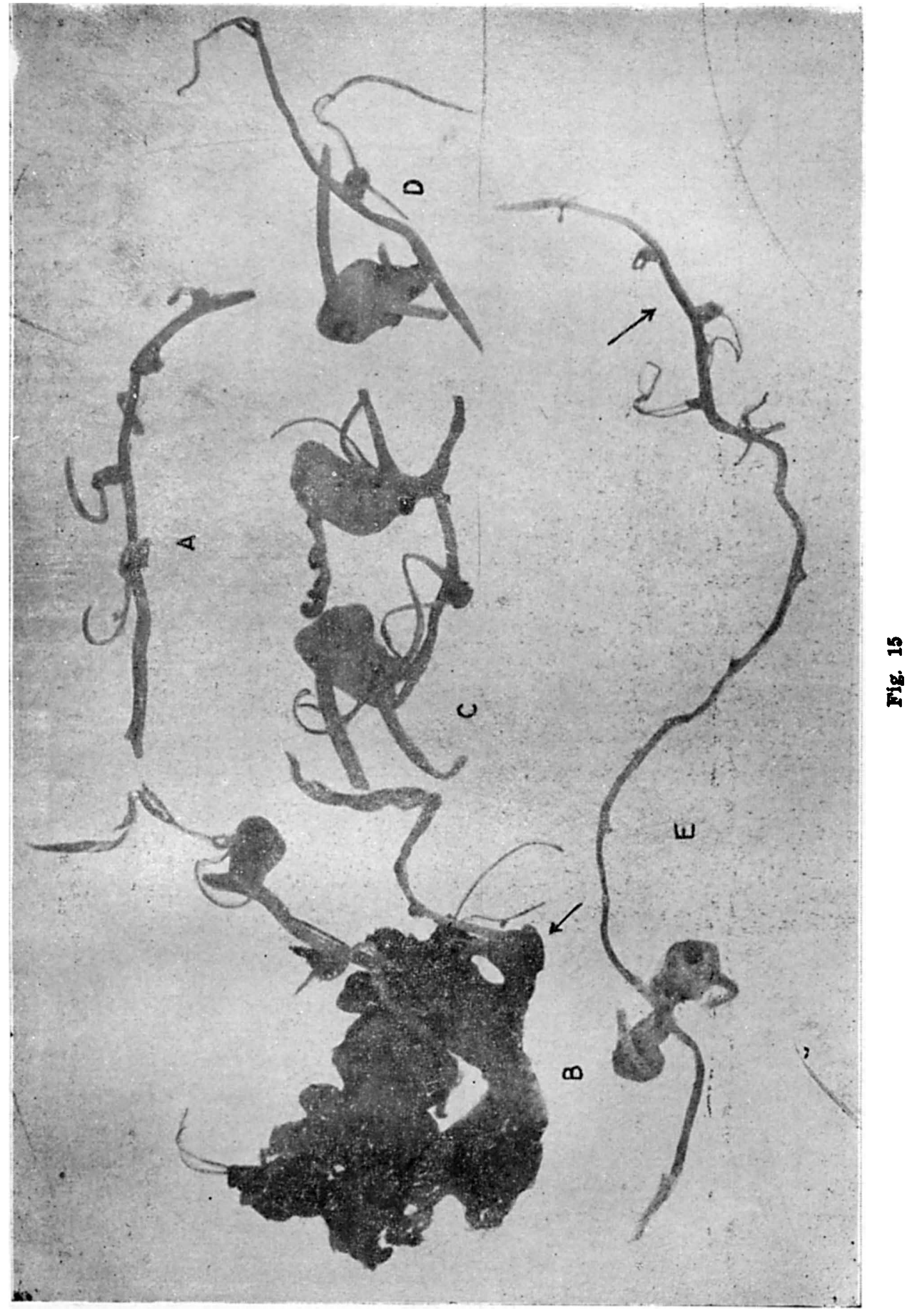




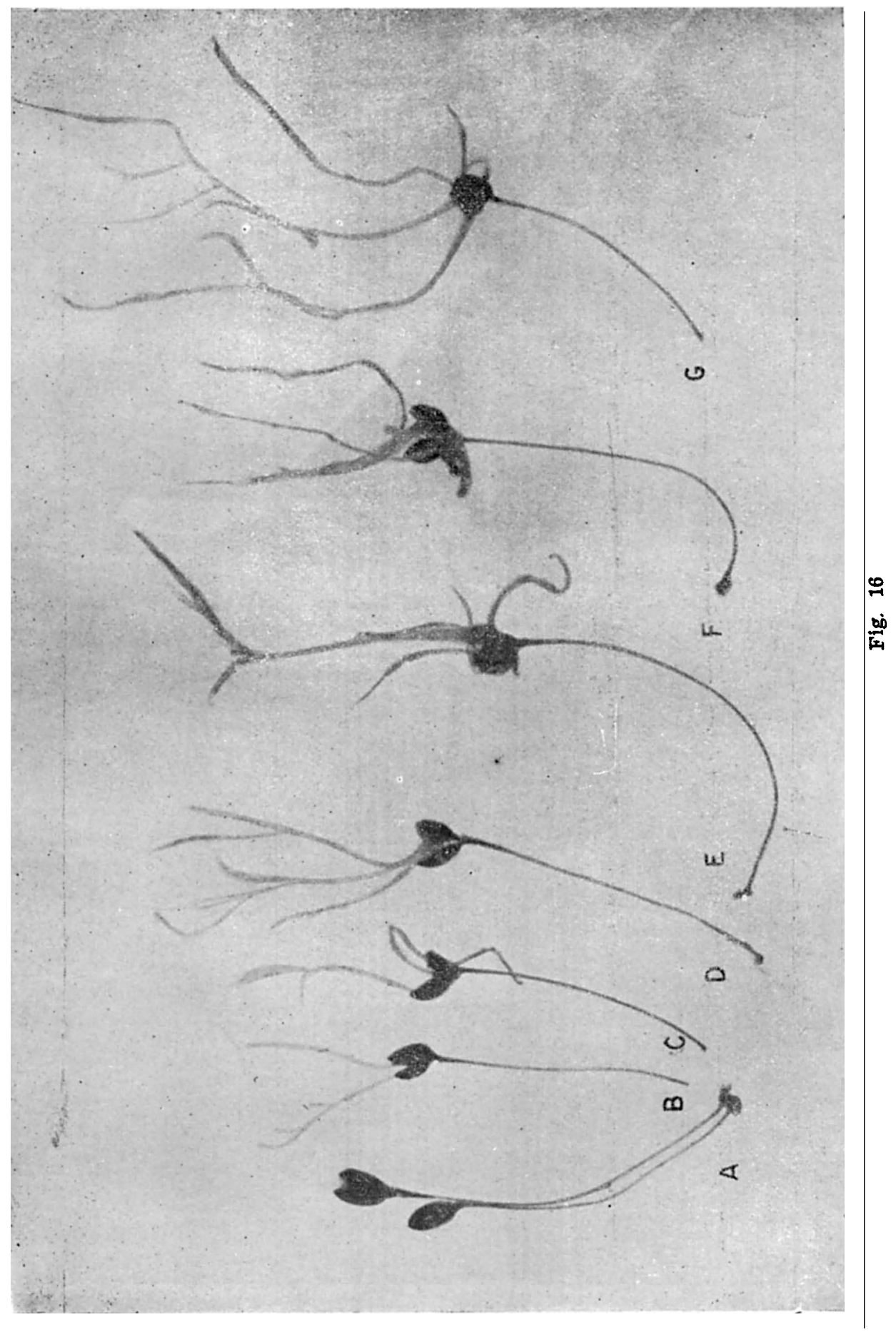




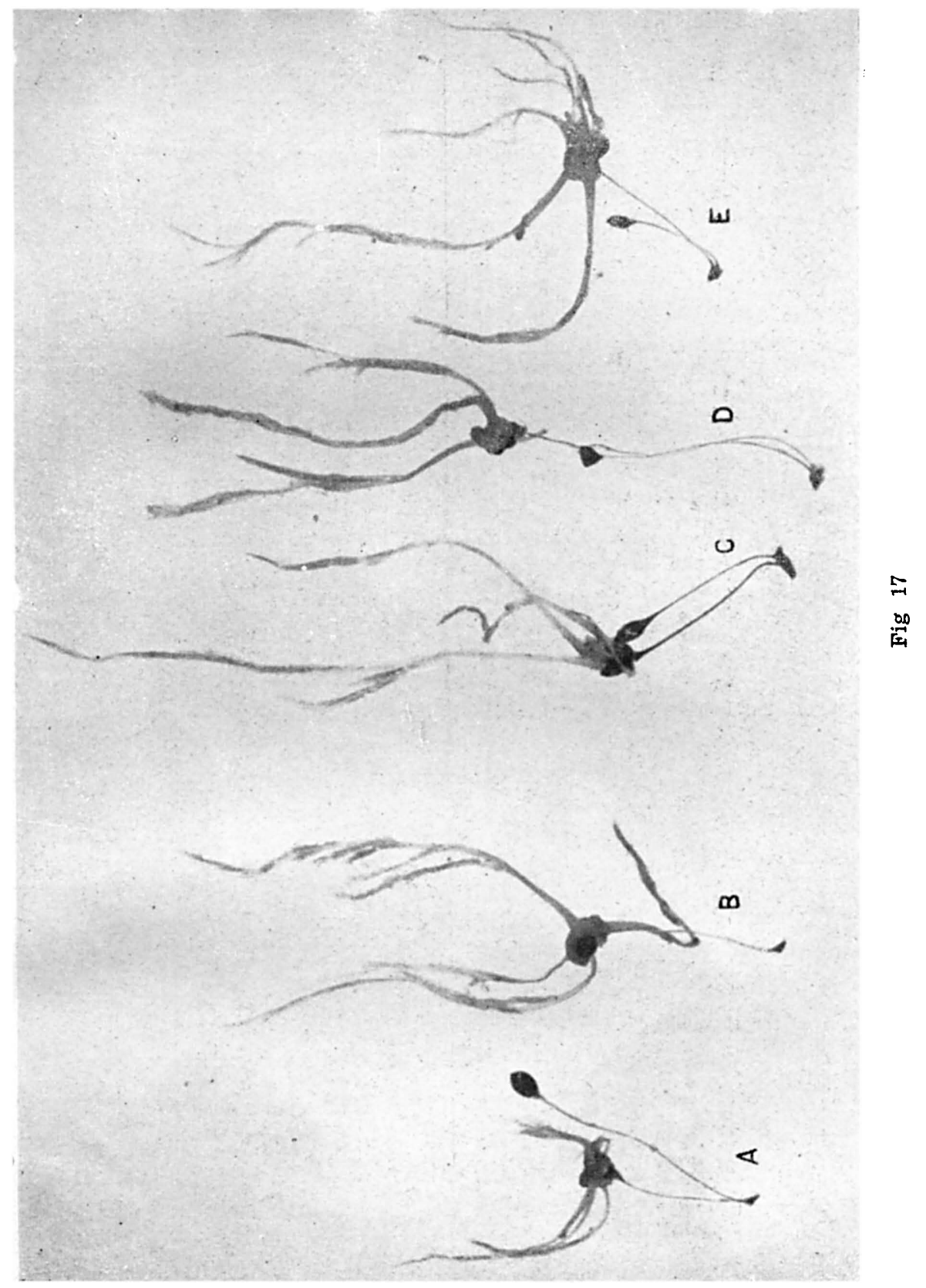





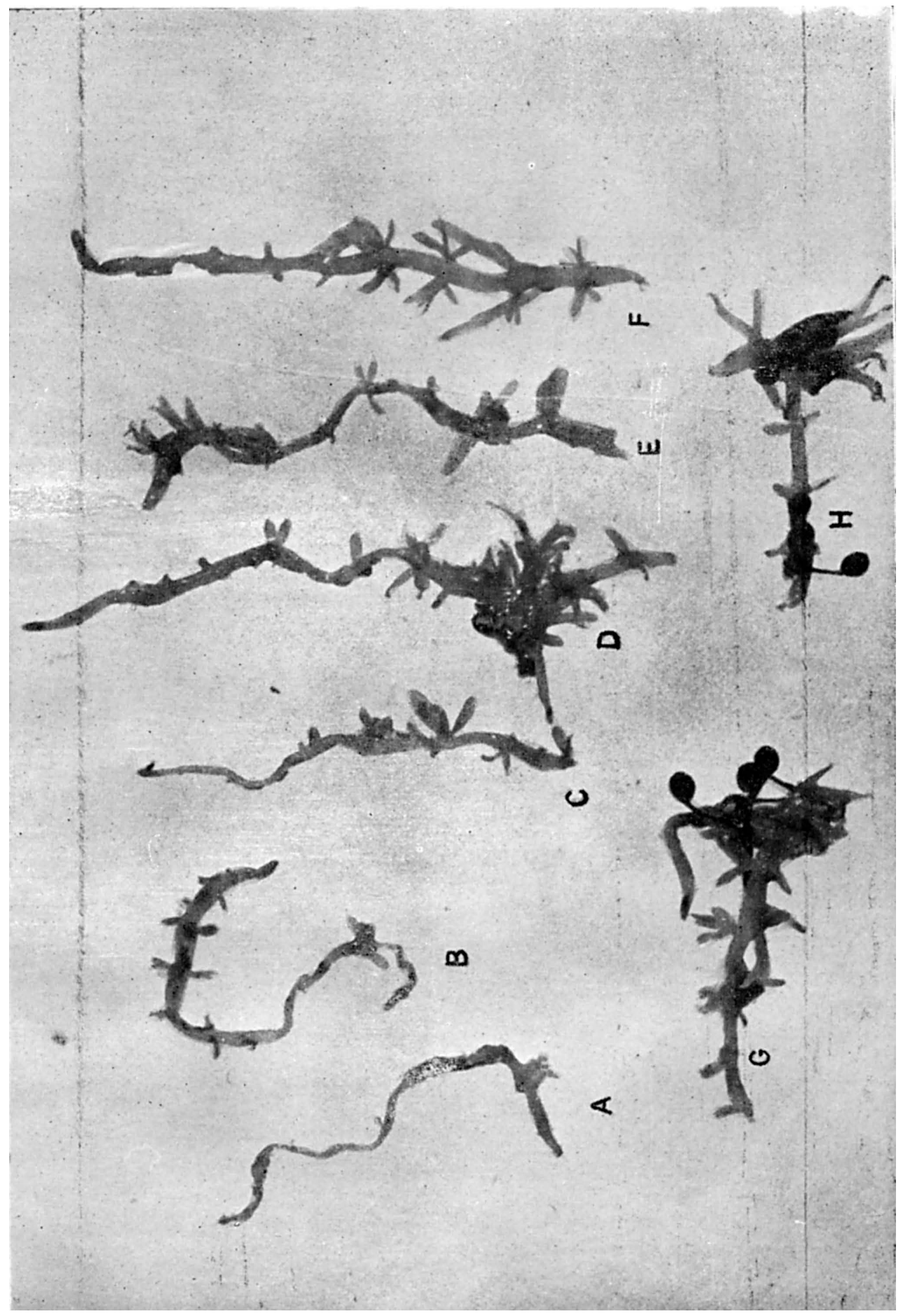

$\stackrel{9}{9}$ 

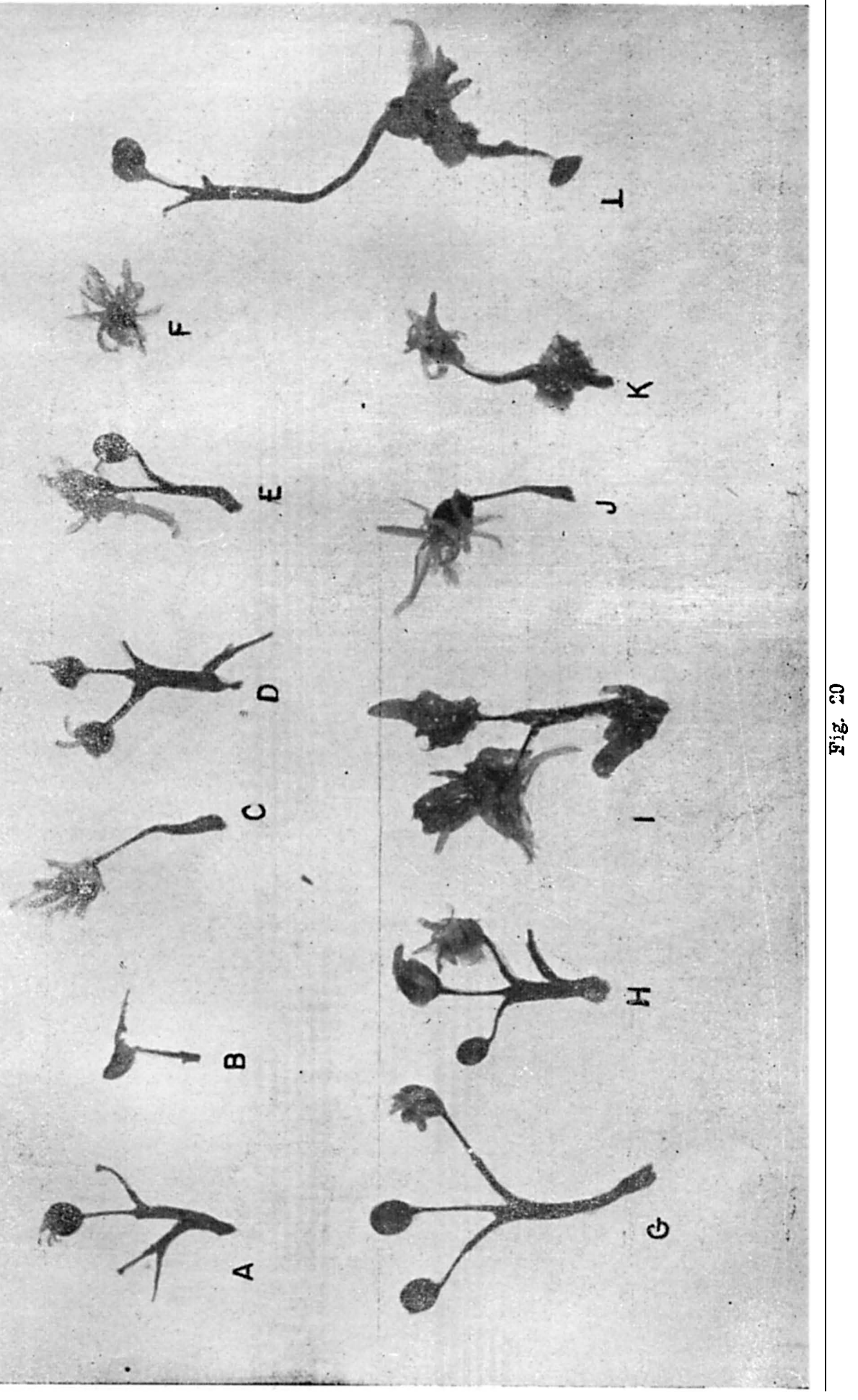


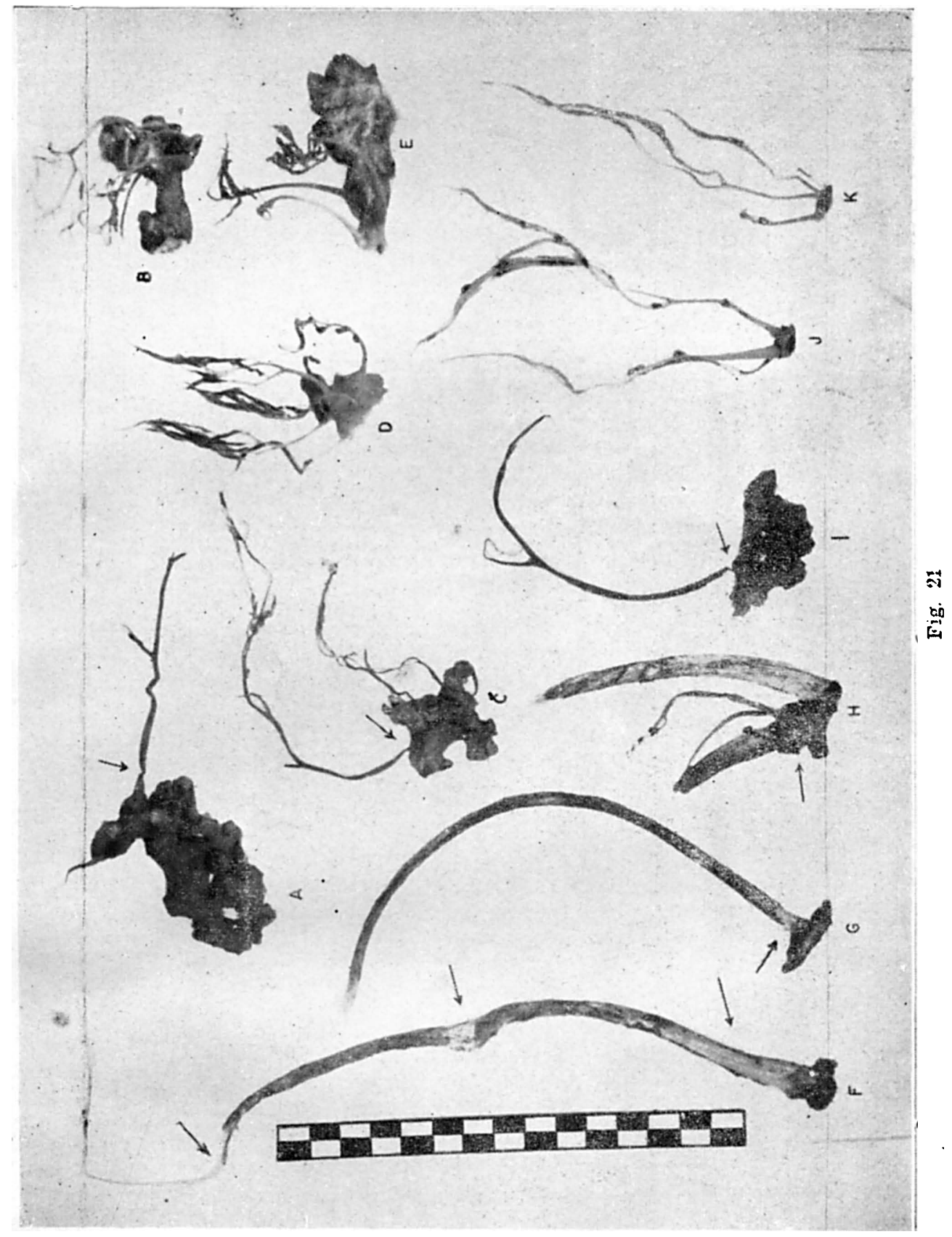




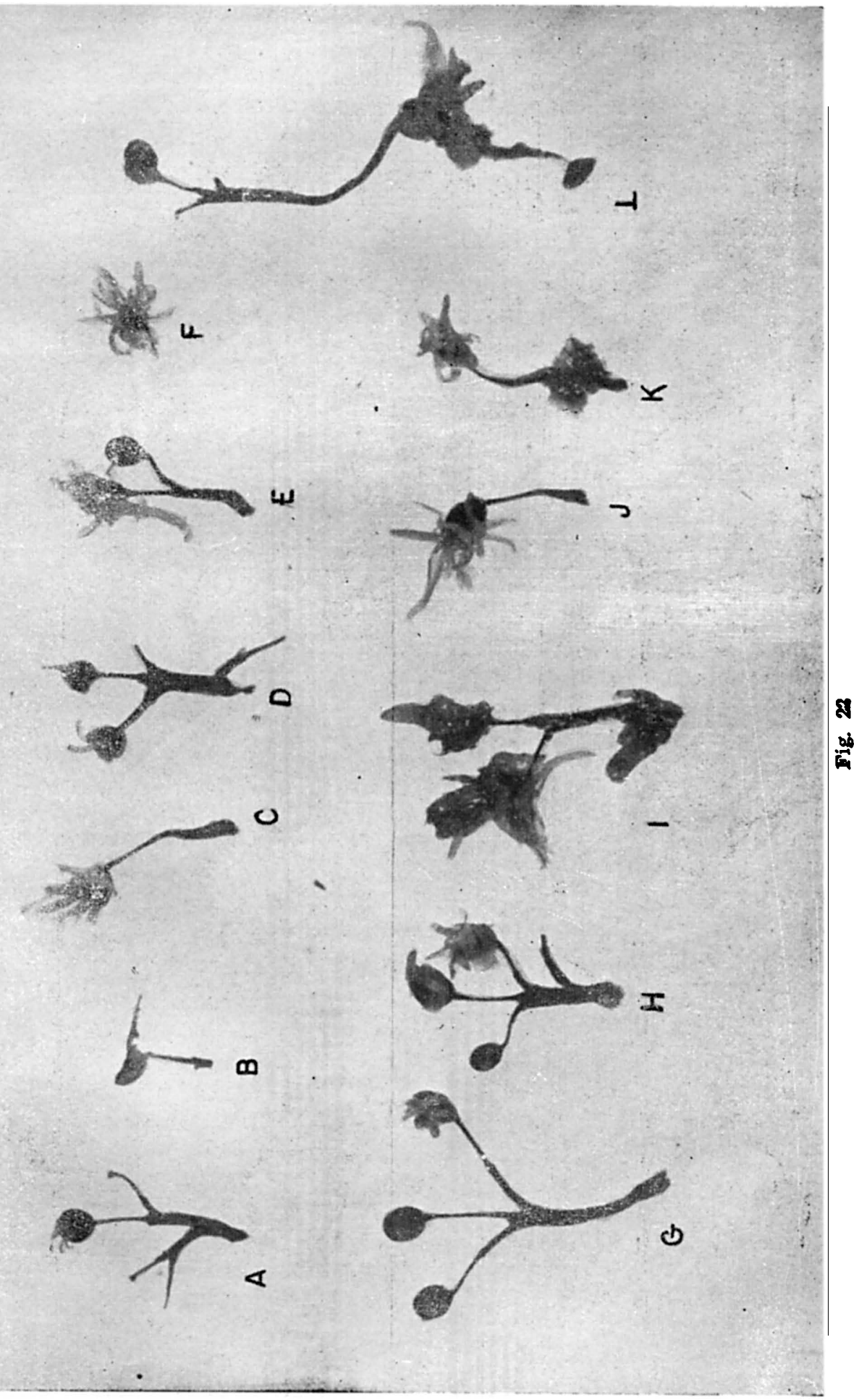




$$
\lambda
$$




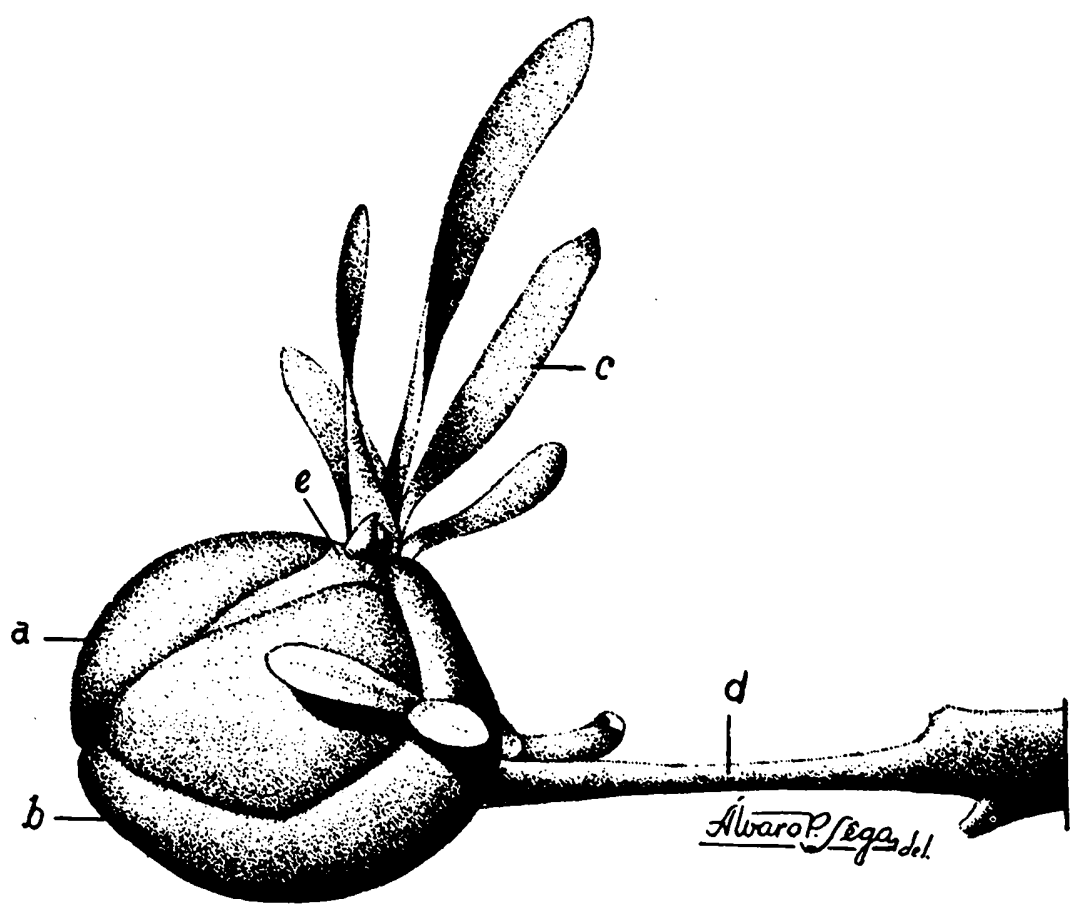

Fig. 24

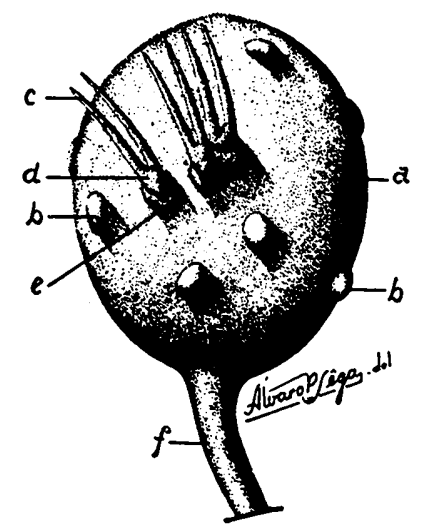

Fig. 25

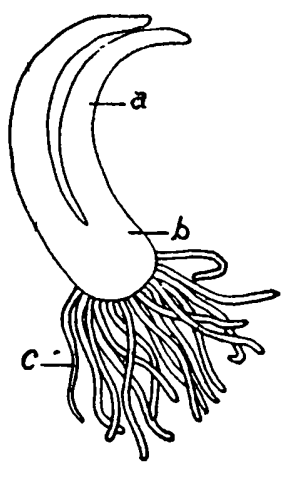

Fig. 26

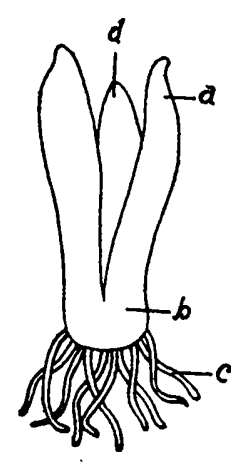

Fig. 27 
transferencia das plantas jovens que, inicialmente, se desenvolvem sôbre cápsulas, pedicelos, etc., para o substrato definltivo - - a rocha - foi verificado, frequentes vêzes, em farto material que incluia vários estágios de desenvolvimento vegetativo (Fgs. 16, 17, 18, 20).

g) As cápsulas, compreendendo, além da placenta (em certos casos), as paredes internas e externas, e os pedicelos dos frutos de ambas as espécies estudadas constituem excelentes e importantes meios para a fixaçăo das sementes. Após os longos períodos de seca, quando tôda a parte vegetativa se destrol, tornam-se os únicos substratos apropriados para o fenómeno da germinação.

h) Iniciada a fase vegetativa e, à medida que progride a submersáo das plantas, acentuam-se, cada vez mais, o crescimento e o desenvolvimento. precisamente durante a época de submersão que as Podostemonaceae encontram 0 ambiente mais adequado ao seus desenvolvimento vegetativo, alcançando, ao mesmo tempo, a máxima distribuiçáo local, mormente a espécie Apinagia Accorsii Toledo, que chega a cobrir todas as rochas situadas da regía frontal da cachoeira.

i) O declínio das águas começa, aproximadamente, em fins de março, com as últimas chuvas. Pode-se, então, avaliar a extensăo do desenvolvimento vegetativo que as plantas alcançaram, durante a fase de enchente. O nivel da correnteza val, dal por diante, baixando gradativamente, até fins de setembro, quando atinge o minimo, ocasião em que o Salto se apresenta com o máximo de rochas expostas.

j) Durante todo o periodo de vazante, que é variável e dependente do regime de chuvas que vigorar, as plantas văo paulatinamente emergindo, ao mesmo tempo que cessa o desenvolvimnto vegetativo, para entrar en atividade o ciclo floral. Antes, porém, os caules de Apinagia que estiveram submetidos as fortes vibrőações da correnteza se destacam (Fig. 21-A,C,F,G, H,I). Todavia, as plantas, que se desenvolveram em regioes de correrteza mais branda, não chegam a perder os seus caules.

k) As gemas floriferas, à medida que văo emergindo, desabrocham. As flores desenvolvem-se rapidamente; a polinizaçăo que é direta efetua-se em plena atmosfera, quando as anteras enxutas e suficientemente dessecadas sofrem a deiscencla, libertando o pólen. Realizada a fecundaçăo, as sementes atingem depressa a maturidade. Como todo o desenvolvimento compreendido entre o desabrochar das gemas e. a frutificaçăo se processa fora da água e como a exposição das plantas e gradativa, em virtude do lento declínio das águas, compreende-se que no Salto existam, a um tempo, todos os estágios do 
ciclo vegetativo ao lado de tódas as fases do desenvolvimento floral.

1) Os rizomas, em contacto com o ar e sob a açăo solar, dessecam-se, transformando-se em placas duras, forteniente inscrustadas às rochas. Mas, se durante a dessecaçăo forem umidecidos, de quando em quando, passam a constituir excelente meio para a retençăo e germinaçăo das sementes.

m) No periodo seguinte de enchente e vazante, repetem-se, para as espécies estudadas, todas as fases do desenvolvinnento vegetativo e floral, assinaladas nesta contribuição.

\section{$\mathrm{V}$ - SUMMARY}

The Author concludes, in this contribution, the estudy he has been making since 1943, on the biological and ecologicai comportment of Apinagia Accorsii Toledo an of Mniopsis Giazioviana Warmg., Podostemonaceae wich are found attached to the rocks of Piracicaba Fall (Piracicaba, S. Paulo, Brazil).

During the flood period, from October until March, the es. pecies mentioned perform their vegetative development. Apigia Accorsii emittes stolons wich produce, laterally, rhizomes: besides, the still alive parts of the remaning rhizomes are regenerated. Mniopsis Glazioviana emittes hemicylindrical rootis, the radicular buds of wich are capable of developing into new plants. For both especies, the germination of seeds may be effected in the following substrata : placents, capsules and pedicels of the fruits, vegetative residues and rhizomatic matter of Apinagia.

Dehiscence of fruits takes place in contact with the air. Seeds adhere to the above mentioned substrata by means of a mucilage resulting from the transformation of its external tegument, in contact with water.

The seedlings have no main root. A large number of root hairs develop around the hypocotyl; their function is fixation.

The attachment of the plants to the rocks is made by means of root hairs and "haptera".

The tranfer of young plants, which develop in the placents, capsules and fruits pedicels, etc., to the rocks takes place when they grow heavy enough as to bend the pedicels.

The fruits and their parts contitute the best mean for the survining of the species in its habitat, for they are the only organs which stick to the rocks, after the complete destruction of the plant's bodies.

The vegetative development is performed exclusively under water, while the floral cycle takes place as soon as the 
plants come in contact with the athmosphere, when they flower and fructiffy rapidly.

\section{VI - AGRADECIMENTO}

O Autor agradece ao Prof. F. G. Brieger o auxilio prestado na tradução dos textos em alemăo.

\section{VII - BIBLIOGRAFIA CONSULTADA}

1) ACCORSI, W, R. - 1944 - Contribuiçăo para o Estudo Biológico e Ecológico das Podostemonaceae do Salto de Piracicaba. Anais da E. S. A. "Luiz de Queiroz" - Piracicata.

2) ENGLER, A. - 1930 - Die Natürlichen Pflanzenfamilién. Band 18.a Verlag Von Wilhelm Engelmann - Leipzig.

3) IHERING, R. - 1940 - Dicionário dos Animais do Brasil. Secretaria da Agricultura - Săo Paulo.

4) JACKSON, B. D. - A Glossary of Botanic Terms. London: Duckworth. Philadelphia: J. B. Lippincott Company.

5) KLEEREKOPER, H. - 1944 - Introduçăo ao Estudo da Limnologia - I - Série Didática - Serviço de Informa.. ções Agrícolas - Ministério da Agricultura - Rio de Janeiro.

6) RAUH, w. - 1937 - Nova Acta Leopoldina.

Neue Folge $\rightarrow$ Band 4 - Nummer 24.

Halle (Saale).

7) TOBLER, F. - 1933 - Beiträge zur Oekologie und Biologie brasilianischer Podostemonaceen.

Flora. Neue Folge 28 Band. pp. 286-300.

8) Warming, E. - 1882 - Etudes sur la Familie des Podos. temonacées.

Deuxiéme Memoire. II - Organes Végétatifs du Castelna. via pprinceps Tul. \& Wedd. Kol. Danske Vidensk. Selsk Skv. 6.a Série II-3.

9) WILLIS, J. C. - 1915 - The Origin of the Tristichaceae and Podostemonaceae - Annals of Botany - vol. XXIX - pp. 299-306.

10) WILLIS J. C. J 1926 - The evolution of the Tristichaceae and Podostemonaceae - Annals of Botany - vol. 40 London. 


\section{VIII - LEGENDAS}

Figs. 1 e 2 - Aspecto geral do Salto de Piracicaba, durante 0 perlodo de séca. Observe-se a enorme porcentagem de rochas expostas, ao lado de alguns braços dágua. (Originals).

Fig. 3 - Um dos muitos braços dágua, cujas características fisicas, quimicas e biologicas permitem o desenvolvimento de Apinagia Accorsil. (Original).

Fig. 4 - Trecho do Salto de Piracicaba em que a corenteza se desdobra em vários ramos. As rochas, dispostas em várias niveis e planos, batidas intensamente pela água, apresentam plantas bem desenvolvidas. (Original).

Fig. 5 - Vista parcial do Salto de Piracicaba, em periodo de séca extrema. (Original).

Fig. 6 - Vista parcial do Salto de Piracicaba, após o inicio do período de chuvas. (Original).

Fig. 7 - Aspecto do Salto de Piracicaba antes das fortes chuvas de 31-10-1944. Na rocha do primeiro plano săo bem visiveis vários rizomas de Apinagia Accorsii, em via de dessecaçăo. (Original).

Fig. 8 - O mesmo trecho do Salto da fig. 7, após as chuvas do dia 31-10-944. Nota-se que a lavagem da rocha do primeiro plano foi intensa. (Original).

Fig. 9 - Outro aspecto do Salto de Piracicaba, após a lavagem das rochas pelas chuvas. (Original).

Fig. 10 - Aspecto do Salto de Piracicaba durante a fase de enchente. Poucas rochas se conservam, ainda, expostas. (Original).

Fig. 11 - Caules de Apinagia Accorsil sob a açăo intensa da correnteza. Observe-se que a curvatura da haste principal se opõe à direça da correnteza. (Original).

Fig. 12 - Alguns rizomas recém expostos, sem caules, mostrando grande número de gemas floriferas em pleno desenvolvimento, ao lado de algumas flores. (Original).

Fig. 13 - Rochas recobertas de grande quantidade de rizomas desprovidos de caules. $O$ aspecto rugoso que oferecem é devido as gemas noriferas prontas para desabrochar. (Original).

Fig. 14 - Formaçóes de Apinagia Accorsii recém expostas; as que eståo ao alcance da correnteza se conservam, ainda, sem caules, como se ve à esquerda da 1.a pessoa. As outras já expostas, e sem caules, mostram flores e frutos em todos os estágios de desenvolvimento. (Original).

Fig. 15 - Fragmentos de rizoma velho (B) emitindo um re- 
bento (regeneraçăo) com um caule novo, em frente à seta, e vários estolhos - A, C, D, E com rizomas em diversos estágios de desenvolvimento. Em $\mathbf{E}$ a seta indica a goteira cheia de partículas terrosas. Nota-se sóbre B um estolho. Aumento $1,2 \times$. (Original).

Fig. 16 - Diversos frutos mostrando os "seedlings" no interior das cápsulas. Alguns rizomas estáo englobando as cápsulas - E, F, G. Aumento 1,5 x (Original).

Fig. 17 - Fases mais adiantadas do desenvolvimento das plantulas de Apinagia Accorsii, cujas sementes germinaram no interior das cápsulas. Nesta fase, os pedicelos já estăo arcados sobre a rocha, em consequencia do péso das plantulas. As cápsulas estzo quase embutidas no jovem rizoma. Pouco menor que o natural. (Original).

Fig. 18 - Estágios bem adiantados de desenvolvimento de plantas de Apinagia Accorsil sóbre cápsulas já embutidas no rizoma. Note-se o tamanho das plantinhas em relaçáo aos pedicelos. Pouco menor que o natural. (Original).

Fig. 19 - Série de raizes de Mniopsis Glazioviana com produçós foliáceas provenientes de gemas radicais. Nas extremidades das raizes A, B, C, D, F, G, percebe-se muito bem 3. colfa, notadamente em C. Durante o crescimento, as raizes podem aderir aos frutos e mesmo em restos de plantinhas, como se ve em $G$ e $H$. Aumento $2 x$. (Original).

Fig. 20 - Série de frutos de Mniopsis Glazioviana mostrando, sobre as cápsulas, os "seedlings" em vários estágios de desenvolvimento, provenientes da germinaçăo das sementes. Propagaçăo por sementes semelhante de Apinagia Accorsii. Aumento 2,5 x. (Original).

Fig. 21 - Rizomas e caules de Apinagia Accorsii, de várias idades. B. C, D, J, K, rizomas novos. A, F, G, H, I, rizomas e caules velhos. $\mathrm{Em} \mathbf{A}, \mathbf{C}, \mathbf{I}$ as setas indicam o ponto em que se dara o desprendimento dos caules. F, G, H săo caules velhos, traumatizados em vários lugares como indica a seta. Na axila dos ramos da figura $H$, desenvolve-se uma plantinha proveniente de semente e que já produziu tres caules. Todos os caules da figura 21 mostram bem a curvatura da haste principal, que se acentua com a idade. Os caules novos das figuras B, C, D, E, J, $\mathbf{K}$ trazem, nas extremidades, as lacinias capiláceas dos ramúsculos, porém, estao unidas devido a umidade. (Original).

Fig. 22 - Rizomas de Aplnagia Accorsii expostos à atmosfera, de diversos tamanhos e idade, em plena fase de florescimento e frutificaçáo. A maloria dos caules dos rizomas adultos se desprendeu. As cicatrizes săo visiveis em A. Há 
flores e frutos em todos os estágios de desenvolvimento. Em A e B pode-se verificar a existência de plantas novas de Apinagia Accorsii crescendo sôbre placas velhas de rizomas. Em E, O têm-se segmentos de estolhos, cujos rizomas recém formados já estão com frutos. Pode-se apreciar muito bem o ciclo floral das plantas, que independe do tamanho e da idade mas sim dos fatores ecológicos.

Fig. 23 - Fruto de Apinagia Accorsii mostrando um "seedling" sóbre a placenta. Aumento $17 \mathrm{x}$. (Original). (Segundo ACCORSI 1944). a - cotilédones; b - haste principal; c - lacínia capilácea do ramúsculo; d - rizoma jovem; e - placenta; f - parede da cápsula; g - pedicelo; $\mathrm{h}$ - nervura da cápsula.

Fig. 24 - Fruto de Mniopsis Glazioviana mostrando um "seedling" em desenvolvimento na placenta, cuja raiz, provida de produçð̃es foliáceas, contorna parte da cápsula. Aumento $19 \mathrm{x}$. (Original). (Segundo ACCORSI 1944). a - parede da cápsula; b - raiz aderente à parede da capsula; c - fôlhas novas; d - pedicelo; e - placenta.

Fig. 25 - Fruto de Mniopsis Glazioviana com sementes e "seedlings" sôbre suas paredes. Aumento $18 \mathrm{x}$. (Original). (Segundo ACCORSI 1944). a - parede do fruto; b - semente; c - cotilédones; e - tegumento da semente; $\mathrm{f}$ pedicelo.

Fig. 26 - "Seedling" jovem de Apinagia Accorsii, encontrado sôbre a placenta; muito aumentado. (Segundo ACCORSII 1944). a - cotilédones; b - hipocótilo; c - pêlos radiculares.

Fig. 2 - "Seedling" jovem de Mniopsis Glazioviana, encontrado no interior do fruto; muito aumentado. (Segundo ACCORSII 1944). a - cotilédone; b - hipocótilo; c pélos radiculares. 